\title{
Deploying Kaizen Events in the Manufacturing Industry: An Investigation into Managerial Factors
}

\author{
Jose Arturo Garza-Reyes* \\ Centre for Supply Chain Improvement \\ The University of Derby \\ Kedleston Road Campus, Derby, UK, DE22 1GB \\ E-mail: J.Reyes@derby.ac.uk \\ Tel. +44(0)1332593281 \\ Christos Christopoulos \\ Warwick Manufacturing Group, University of Warwick \\ International Manufacturing Centre, University of Warwick \\ Coventry, UK, CV4 7AL \\ E-mail: C.Christopoulos@warwick.ac.uk \\ Anil Kumar \\ Guildhall School of Business and Law, \\ London Metropolitan University, London, UK \\ E-mail: anilror@gmail.com

\section{Sunil Luthra} \\ Department of Mechanical Engineering
}

Ch. Ranbir Singh State Institute of Engineering \& Technology, Jhajjar-124103, Haryana, India

E-mail: sunilluthra1977@gmail.com

\section{Fernando González-Aleu}

Departamento de Ingenieria

Universidad de Monterrey

San Pedro Garza García, N.L., México

E-mail: fernando.gonzalezaleu@udem.edu

\section{Vikas Kumar}

Bristol Business School

University of the West of England

Coldharbour Ln, Bristol, UK, BS16 1QY

E-mail: Vikas.Kumar@uwe.ac.uk

Tel. +44(0)1173283466

\section{Bernardo Villarreal}

Departamento de Ingenieria

Universidad de Monterrey

I. Morones Prieto 4500 Pte

San Pedro Garza Garcia, N.L., Mexico

E-mail: bernardo.villarreal@udem.edu

Tel. +528182154521 


\section{Deploying Kaizen Events in the Manufacturing Industry: An Investigation into Managerial Factors}

Abstract: Despite the extensive research on Continuous Improvement (CI), limited reflection has been reported regarding the managerial factors needed to successfully deploy Kaizen Events (KEs). This study investigates various managerial aspects that affect the implementation of KEs. After conducting a literature review and gathering experts' inputs, the objectives of the study and six research questions were formulated. A survey questionnaire responded by 175 manufacturing organisations was designed and validated. A combined approach of descriptive statistics and one-way ANOVA tests were used to analyse the collected data. Besides other 'soft' aspects, the results determine: (1) the drivers and barriers in the pre-implementation stage of KEs; (2) the critical success factors and challenges related to the implementation stage of KEs; (3) the reasons that result in unsuccessful KEs; and (4) the reasons that stop organisations from running KEs. The study provides insights into an under-researched topic by looking at different phases of KEs implementation. The study contributes to the contingency and the RBV theories by offering an understanding of the importance of different contingencies and resources planning for KEs implementation. The findings are beneficial for industrialists who may aim at driving CIs in their organisations through the implementation of KEs.

Keywords: Continuous improvement; Kaizen; Kaizen Events; Lean manufacturing; Lean implementation.

\section{Introduction}

Over the last 40 years, some of the most popular and effective practices and tools for achieving operational excellence have been derived from Lean Manufacturing (LM) (Choudhary et al. 2019; Albliwi et al. 2015; Forrester et al. 2010). Fundamentally, LM's objective is to eliminate non-value adding activities through continuous incremental improvements (Abolhassani et al. 2016). Among the plethora of tools and techniques that LM utilises, Kaizen Events (KEs) are considered as an increasingly implemented improvement method (Carvalho Ferreira and Abreu Saurin 2019; Garza-Reyes et al. 2018; Chan and Tay 2018; Glover et al. 2015). It is based on the wider Japanese philosophy "Kaizen" that stands for "Continuous Improvement (CI)" (ÁlvarezGarcía et al. 2018; Farris et al. 2009). More specifically, "KEs are structured projects in which dedicated cross-functional teams apply LM tools to a specific area, focusing on CI and to achieve specific goals in an accelerated time frame (i.e. kaizen) mind-set” (Cannas et al. 2018; 
Farris et al. 2009). KEs focus on wastes elimination and the enhancement of particular processes by using low-cost solutions through creativity and sometimes other lean techniques (Cherrafi et al. 2019; Chen et al. 2010).

Kaizen, KEs and their management aspects play a central role for organisations that want to successfully adopt and sustain LM initiatives, as they are considered as the drivers and basis for the whole lean philosophy (Line 2007) and have gained increased popularity among organisations (Glover et al. 2014). However, there is still a lack of thorough and systematic research concerning the managerial aspects of this mechanism and its successful implementation (Kumar et al. 2018a, 2018b; Glover et al. 2014; Farris et al. 2009; Farris et al. 2008; Farris et al. 2006). In this context, the current literature remains limited as there is not a clarified converge of the information and knowledge associated with various characteristics and phases of KEs (Glover et al. 2014), mainly due to the existence of anecdotal and no systematic and empirical evidence (Glover et al. 2014; Farris et al. 2009; Farris et al. 2008; Farris et al. 2006).

KEs related literature has recently seen a significant growth owing to its increased utilization as an effective process improvement tool. The literature suggests that understanding the longterm impact of KEs on organisational success requires careful investigation of related activities and their impact (Vo et al. 2019). Additionally, the current relevant literature lacks studies that follow quantitative techniques to investigate KEs, i.e. qualitative investigations constitute the majority of previous studies. Furthermore, among the investigated practices, the authors have identified some divergences with respect to the implementation of KEs, as these are interpreted by academics and practitioners respectively (Cherrafi et al. 2019). Thus, as Forza (2002) argues, the theory-practice gap needs to be addressed in order to make research more useful to practitioners. Also, researchers in the field of operations management highlight that in order to enrich and upgrade the body of knowledge in a specific topic, the use of both quantitative and qualitative methodologies from different research perspectives is critically necessary (Khan et al. 2019; Gonzalez-Aleu et al. 2018; Chan and Tay 2018; Glover et al. 2013a; Ng et al. 2012). Therefore, there is a need for such quantitative empirical research on this topic. As per the contingency theory perspective, there is not a generalised path to measure the impact of KEs across different stages of development based on managerial factors (Andreadis et al. 2017). Sunder and Prashar (2020) and Sousa and Voss (2008) recommend the contingency approach as an appropriate method for examining important factors that distinguish contexts. CI has the overall objective of implementing KEs through different stages but there is not a comprehensive way to succeed with such implementation (Sunder and Prashar 2020; Sitkin et al. 1994). The implementation of KEs itself depends on multiple contingencies that should be investigated 
across deployment stages so that industry managers can effectively employ them. Thus, in this context, an empirical investigation is required to understand the significance of some managerial factors for the successful deployment of KEs and make a contribution from a contingency theory's perspective. This is the reason that encouraged the authors to follow this approach. Companies must understand the interplay of their strategic resources and their capability to gain a competitive advantage as per the Resource-Based View (RBV) theory (Hitt et al. 2016; Conner and Prahalad 1996). The motivation of this study is to overcome the aforementioned issues and fill the gaps in the scholarly literature. Sunder and Prashar (2020) studied the critical failure factors of CI deployments based on stage-wise results. After conducting an extensive literature review on different implementation stages of KEs, no studies discussing the holistic implementation of KEs through different stages were identified.

To fulfil these research gaps, this study addresses the following research objectives:

- To identify and evaluate the drivers and barriers in the pre-implementation stage of KEs;

- To identify and evaluate the Critical Successful Factors (CSFs) and barriers in the implementation stage of KEs; and

- To evaluate the reasons in the post-implementation stage that lead to unsuccessful KEs and those that force companies to stop running them.

To fulfil the above-mentioned research objectives, the present study investigates various managerial aspects that have an effect on the implementation of KEs. The novelty of this study is not only based on investigating the contingencies of the deployment of KEs across the pre, during and post-implementation stages but also to understand the interplay of companies' strategic resources for the effective implementation of KEs. A combined approach of descriptive statistics and one-way ANOVA tests were used to achieve the objectives of the study. This combined approach can be useful to draw initial conclusions in research with an exploratory nature (Chauhan et al. 2020; Piyathanavong et al. 2019; Andreadis et al. 2017).

Along with the literature review, the formulation of the Research Questions (RQs) is provided in Section 2. The methodology and data analysis used are presented in Sections 3 and 4. Section 5 discusses the findings, along with the implications. Section 6 provides the theoretical and practical contributions along with the unique contributions of the present research. Finally, Section 7 presents the conclusions, limitations and future research directions.

\section{Literature Review}


This section comprises three sub-sections. Section 2.1 reviews the literature on KEs implementation across different stages. Section 2.2 determines the factors that contribute to their successful/unsuccessful implementation, whereas Section 2.3 identifies research gaps concerning such deployment.

\subsection{Kaizen Events}

In the past, various researches related to both Kaizen and KEs as well as their utilisation and implementation within organisations have been conducted (Villar-Fidalgo et al. 2019; Cherrafi et al. 2019; Marin-Garcia et al. 2018; Cannas et al. 2018; Glover et al. 2014). These researches have mainly focused on the investigation of the principles, i.e. rules of doing the activities by using a framework which stands for planning, organising, leading and controlling Henri Fayol (1841-1925) (Ballou 2007).

Specifically, previous research can be summarised as centred on: (1) wow Kaizen is adopted and implemented within organisations in the broader context of LM, mainly defining and discussing its most important practices and tools/techniques (e.g. Cannas et al. 2018; Glover et al. 2014; Stewart 2011; Smalley and Kato 2010; Mika 2006; Farris and Van Aken 2005); (2) the benefits of Kaizen and KEs, their drivers, facilitators and CSFs, as well as proposed implementation practices (e.g. Marin-Garcia et al. 2018; García-Alcaraz et al. 2017; Glover et al. 2014; Howell 2011; Manos 2007; Farris et al. 2006); (3) the implementation-plan in terms of task-design, team-design, organisational processes and policies, and management role for successfully exploiting the benefits of successful KEs (e.g. Cherrafi et al. 2019; Glover et al. 2014; Uppal et al. 2012; Zanin et al. 2011; Farris et al. 2009; Sprovieri 2008; Lee 2007; Farris et al. 2006; Palmer 2001; Sheridan 2000); (4) the barriers/challenges and managerial implications that organisations face during the utilisation and implementation of KEs (e.g. Marin-Garcia et al. 2018; Glover et al. 2014; Bhasin 2012); (5) to a very small extent, unsuccessful cases of KEs and the reasons that led to this lack of success (e.g. Farris et al. 2008; Cole 1992; Sitkin 1992); and other researchers have focused on (6) the application or measurement of Kaizen not seen from the implementation point of view (e.g. Villar-Fidalgo et al. 2019; Cherrafi et al. 2019; Carvalho Ferreira and Abreu Saurin 2019).

After conducting a literature review on KEs, it was important to understand the different implementation phases (i.e. pre-implementation, implementation and post-implementation) of KEs. This aimed at providing insights to industry managers and enhance their knowledge in regards to: the main drivers in the pre-implementation stage that lead organisations to utilise KEs, the main barriers in the pre-implementation stage that make organisations not to implement KEs, the divergent CSFs that are considered more important for the successful implementation 
of KEs, the main barriers that organisations face during the implementation of KEs, and the reasons in the post-implementation stage that lead to unsuccessful KEs. Through this, the study contributes to the contingency (Scott, 1981) and the RBV (Barney, 1991) theories by offering an understanding of the implementation situation of KEs and determining the strategic resources, e.g. managerial factors, that a firm can exploit to achieve sustainable competitive advantage and measure the impact of KEs across different stages of deployment. In this context, few studies have contributed to these theories. For example, Sousa and Voss (2008) discussed contingency research in operations management practices while Larson and Foropon (2018) studied, based on an organisational theory perspective, the improvement of processes in humanitarian operations. Sunder and Prashar (2020) conducted an empirical examination of critical failure factors of continuous improvement deployment from a contingency theory perspective. Nevertheless, these studies did not focus on KEs and its implementation stages.

Mainly, the literature could be structured based on the different phases, i.e. preimplementation, implementation and post-implementation, which a KE goes through when deployed. These phases are explained in the following sub-sections.

\subsubsection{Kaizen Events Pre-Implementation Phase}

Kaizen and KEs play an undisputed role in LM and the adoption of the overall lean philosophy (Cannas et al. 2018). Consequently, this suggests these philosophies and methodologies as two integral and aligned parts. However, most of the studies do not lean completely towards this perception, supporting that Kaizen often, but not always, utilises lean tools and is applied within the general LM context (Glover et al. 2013b; Kirby and Greene 2003; Taylor et al. 2001). Also, according to Van Aken et al. (2010), Farris et al. (2006) and Kumar and Harms (2004), KEs can be seen as a Kaizen and Lean-implementation means in an organisation, as they consist of a significant part within the whole lean management system, being mainly employed in conjunction with other lean mechanisms.

In recent years, numerous organisations have been making efforts to implement KEs to swiftly introduce change and to make a culture of CI with the increased use of LM practices. However, organisations lack systematic, research-based guidance on how to best design and implement KE improvement programmes and how to best assess their results (Van Aken et al., 2010). Nevertheless, no studies have previously focused on investigating whether KEs are used, or can be used, as a standalone improvement mechanism within an organisation that has not implemented LM. Apart from Glover et al. (2014) and Van Aken et al. (2010), most studies argue that KEs are applied within the general LM context (Kumar et al. 2018a, 2018b; Glover et 
al. 2013b; Kirby and Greene 2003; Taylor et al. 2001). Less scholarly literature is available where the authors discuss the drivers which play a significant role in the pre-implementation stage that lead organisations to utilise KEs and the barriers that make organisations not to implement KEs. Following Janjić et al. (2019), Aminuddin et al. 2016 and Glover et al. (2014) suggestions, and Kamble et al. (2020) recommendation for future research, we proposed the following RQs:

RQ1: Which are the main drivers in the pre-implementation stage that lead organisations to utilise KEs?

RQ2: Which are the main barriers in the pre-implementation stage that make organisations not to implement KEs?

\subsubsection{Kaizen Events Implementation Phase}

Through a systematic review of the literature, Glover et al. (2014) and Farris et al. (2006) identified twenty-two practices as the most common activities deployed during KEs and classified them into five categories, namely: task design, team design, organisation, event process and broader context. These are also aligned to the enablers defined by Carvalho Ferreira and Abreu Saurin (2019), Glover et al. (2014) and Farris et al. (2006). The enablers are categorised as 'convergent' practices, (i.e. practices that were found to prevail in all cases reported in the literature), 'variant' practices, (i.e. practices that were found in some, but not all, Kaizen Event researches/cases reported in the literature), and 'divergent' practices, (i.e. practices that were found to be contradictorily recommended in the literature as best Kaizen Event practices). Table 1 presents such practices and their classification.

Table 1. KEs practices (adapted from Glover et al., 2014)

\begin{tabular}{|c|c|c|c|c|c|c|c|c|}
\hline \multirow[b]{2}{*}{ Practice } & \multicolumn{5}{|c|}{ Category } & \multicolumn{3}{|c|}{ Type of Practice } \\
\hline & $\begin{array}{c}\text { Task } \\
\text { design }\end{array}$ & $\begin{array}{c}\text { Team } \\
\text { design }\end{array}$ & Organisation & $\begin{array}{c}\text { Event } \\
\text { process }\end{array}$ & $\begin{array}{l}\text { Broader } \\
\text { context }\end{array}$ & Convergent & Variant & Divergent \\
\hline Event duration & $\bullet$ & & & & & & $\bullet$ & \\
\hline $\begin{array}{l}\text { Team authority/ } \\
\text { autonomy }\end{array}$ & $\bullet$ & & & & & $\bullet$ & & \\
\hline Problem scope & $\bullet$ & & & & & $\bullet$ & & \\
\hline Event goals & $\bullet$ & & & & & & $\bullet$ & \\
\hline Team size & & $\bullet$ & & & & & $\bullet$ & \\
\hline Cross-functional teams & & $\bullet$ & & & & $\bullet$ & & \\
\hline Team structure & & $\bullet$ & & & & & $\bullet$ & \\
\hline $\begin{array}{l}\text { Functional and } \\
\text { hierarchical } \\
\text { heterogeneity }\end{array}$ & & $\bullet$ & & & & & $\bullet$ & $\bullet$ \\
\hline $\begin{array}{l}\text { Team member problem- } \\
\text { solving abilities }\end{array}$ & & $\bullet$ & & & & & & $\bullet$ \\
\hline Team member attitudes & & $\bullet$ & & & & $\bullet$ & & \\
\hline
\end{tabular}




\begin{tabular}{|c|c|c|c|c|c|c|}
\hline Management support & $\bullet$ & & & $\bullet$ & & \\
\hline Resource support & $\bullet$ & & & & & $\bullet$ \\
\hline Rewards/recognition & $\bullet$ & & & $\bullet$ & & \\
\hline $\begin{array}{l}\text { External } \\
\text { communication }\end{array}$ & $\bullet$ & & & $\bullet$ & & \\
\hline Event planning process & $\bullet$ & & & & & $\bullet$ \\
\hline Training & $\bullet$ & & & & $\bullet$ & \\
\hline Action orientation & & $\bullet$ & & $\bullet$ & & \\
\hline $\begin{array}{l}\text { Problem-solving } \\
\text { tools/techniques }\end{array}$ & & $\bullet$ & & & $\bullet$ & \\
\hline Team coordination & & $\bullet$ & & $\bullet$ & & \\
\hline $\begin{array}{l}\begin{array}{l}\text { Kaizen event } \\
\text { deployment }\end{array} \\
\end{array}$ & & & $\bullet$ & & & $\bullet$ \\
\hline $\begin{array}{l}\text { Organisational policies } \\
\text { and proceedings }\end{array}$ & & & $\bullet$ & $\bullet$ & & \\
\hline $\begin{array}{l}\text { Kaizen event } \\
\text { programme support }\end{array}$ & & & $\bullet$ & & $\bullet$ & \\
\hline
\end{tabular}

Glover et al. (2014) suggest the practices presented in Table 1 as those success factors needed to effectively conduct KEs. However, further research is needed, particularly, in relation to the divergent factors as they have shown to be incongruent during the conduction of KEs (Farris et al., 2006). Critical Success Factors (CSFs) could be explained as those that cover all managerial areas across the organisation and that are the element for best performance (Mohammad and Oduoza 2019). Therefore, a better understanding of the divergent CSFs could help to better manage the KEs implementation and may reduce the likelihood of KEs implementation failures. Thus, within the context of this study, authors have specifically focused on the divergent CSFs as they are also a source of contradiction, bringing a lack of clarity to the KEs research and scholarly literature. This can consequently result in significant managerial implications that may hinder the successful implementation of KEs (Janjić et al. 2019; Gonzalez-Aleu et al. 2018).

Various researchers (Tavana et al. 2020; Kurpjuweit et al. 2019; Marin-Garcia et al. 2018; Erdogan et al. 2017) have suggested that organisations may face several hurdles in the implementation phase of KEs; therefore, identifying these barriers is necessary to effectively address them. Hence, the following RQs have been conveyed:

RQ3: Which divergent CSFs are considered more important for the successful implementation of KEs?

RQ4: Which are the main barriers that organisations face during the implementation of KEs?

\subsubsection{Kaizen Events Post-Implementation Phase}

Evidence in the scholarly literature suggests KEs as a popular improvement approach (GarcíaAlcaraz et al. 2013; Farris et al. 2009). Despite its popularity and effectiveness, not all organisations have embarked on CI using KEs as an underpinning approach to achieve it. 
Arguably, one possible reason that prevents organisations from deciding whether to implement KEs is a failure during past efforts. Thus, by identifying the reasons that lead to unsuccessful KEs, organisations could more easily determine whether to undertake KEs initiatives and successfully implementing them. However, companies need to implement specific policies and procedures in order to support KEs (Glover et al. 2014). For example, post-event performance measures are of significant importance to sustain KEs (Glover et al. 2011; Stone 2010). Also, the frequency of KEs deployment is important (Garcia-Alcaraz et al. 2017b; García-Alcaraz et al. 2013). However, according to some scholars, this factor presents divergent outcomes and potentially negative effects; some researchers suggest to conduct KEs regularly (Huls 2005), whereas others recommend them quarterly (Ortiz 2006), or even infrequently as to achieve significant improvements in targeted areas (Sheridan and Jusko 2000). Particularly, Friedli (1999) does not suggest the so-called 'kamikaze' Kaizen strategy, where haphazard and unsystematic KEs take place without appropriate progress monitoring.

Also, Van Aken et al. (2010) study showed that KEs that are deployed as part of a wider CI programme and aligned to the overall organisational strategy present increased success and effectiveness, but without suggesting how frequently these events should be conducted. Following Erdogan et al. (2017), Medinilla, Á. (2014), Glover et al. (2014) and Van Aken et al. (2010) suggestions, and Gandhi et al. (2019) proposal for future research, the following research questions were articulated to investigate the success and sustainment of KEs:

RQ5: Which are the reasons in the post-implementation stage that lead to unsuccessful KEs? RQ6: Which are the reasons in the post-implementation stage that lead to stop organisations from running KEs?

\subsection{Identification of Variables to the Successful/Unsuccessful Implementation of Kaizen Events}

In order to address the six RQs formulated in the previous section, an extensive literature was conducted to identify some key variables pertaining to the implementation of KEs. These included the key main factors that drive the operational and financial results of a business (Berry 1999) and that led organisations to implement KEs; the main barriers that make organisations not to implement KEs; the CSFs as the minimal number of tasks needed to guarantee satisfactory results and the competitive performance of a company (Luthra et al. 2015) that contribute to the successful implementation of KEs; the main barriers that organisations face during the implementation of KEs; and the main reasons that lead to successful/unsuccessful KEs and stop organisations from running them. Various keywords such as Pre-implementation, 
Implementation and Post-implementation phases of KEs; Drivers/Barriers/Challenges in the preimplementation of KEs; Divergent CSFs and barriers to the successful implementation of KEs; Key reasons for unsuccessful KEs were searched on Google Scholar and Google search engines to explore the literature published in journals, conferences proceedings, reports and books. The corresponding papers were then downloaded, reviewed and analysed. A brief description of the variables that contributed to the successful/unsuccessful implementation of KEs is provided in Table 2.

Table 2. Identification of variables that contributed to the successful/unsuccessful implementation of Kaizen events

\begin{tabular}{|c|c|c|}
\hline Variables & A brief definition & References \\
\hline \multicolumn{3}{|c|}{$\begin{array}{l}\text { Pre-Implementation Stage } \\
\end{array}$} \\
\hline \multicolumn{3}{|c|}{ Main drivers that led organisations to implement KEs } \\
\hline Reduction of waste & $\begin{array}{l}\text { This driver is related to how KEs } \\
\text { practices help organisations to } \\
\text { reduce waste }\end{array}$ & $\begin{array}{l}\text { Vo et al. (2019); Kumar } \\
\text { et al. (2018a); Lima et al. } \\
(2018)\end{array}$ \\
\hline $\begin{array}{l}\text { Improvement on } \\
\text { employees' skills }\end{array}$ & $\begin{array}{l}\text { The CI of employees' skills is a } \\
\text { driving force to implement KEs }\end{array}$ & $\begin{array}{l}\text { Khan et al. (2019); } \\
\text { Habidin et al. (2018); } \\
\text { Glover et al. (2011) }\end{array}$ \\
\hline Increase in productivity & $\begin{array}{l}\text { It is related to how the } \\
\text { implementation of KEs helps an } \\
\text { organisation to increase productivity }\end{array}$ & $\begin{array}{l}\text { Vo et al. (2019); Khan et } \\
\text { al. (2019); Habidin et al. } \\
(2018)\end{array}$ \\
\hline Improvement of quality & $\begin{array}{l}\text { It is related to how the } \\
\text { implementation of KEs helps an } \\
\text { organisation to improve quality }\end{array}$ & $\begin{array}{l}\text { Vo et al. (2019); Khan et } \\
\text { al. (2019); Glover et al. } \\
\text { (2011) }\end{array}$ \\
\hline $\begin{array}{l}\text { Improvement of space } \\
\text { utilisation }\end{array}$ & $\begin{array}{l}\text { This driver relates to how the } \\
\text { implementation of KEs helps an } \\
\text { organisation to the improvement of } \\
\text { space utilisation }\end{array}$ & $\begin{array}{l}\text { Khan et al. (2019); Janjić } \\
\text { et al. (2019); Habidin et } \\
\text { al. (2018) }\end{array}$ \\
\hline $\begin{array}{l}\text { Increase and improvement } \\
\text { of communication among } \\
\text { administrative departments }\end{array}$ & $\begin{array}{l}\text { The implementation of KEs } \\
\text { practices supports an organisation to } \\
\text { increase and improve } \\
\begin{array}{l}\text { communication among } \\
\text { administrative departments }\end{array}\end{array}$ & $\begin{array}{l}\text { Vo et al. (2019); Khan et } \\
\text { al. (2019); Janjić et al. } \\
\text { (2019); Suárez-Barraza } \\
\text { and Ramis-Pujol (2010) }\end{array}$ \\
\hline \multicolumn{3}{|c|}{ Main barriers that make organisations not to implement KEs } \\
\hline Insufficient awareness & $\begin{array}{l}\text { This barrier is related to the } \\
\text { awareness that is required for the } \\
\text { proper implementation of KEs } \\
\text { activities but businesses have } \\
\text { insufficient awareness about it }\end{array}$ & $\begin{array}{l}\text { Janjić et al. (2019); } \\
\text { Stelson et al. (2017); } \\
\text { Farris et al. (2008) }\end{array}$ \\
\hline $\begin{array}{l}\text { Insufficient implementation } \\
\text { knowledge }\end{array}$ & $\begin{array}{l}\text { The knowledge required to } \\
\text { implement KEs activities but } \\
\text { businesses have an insufficient level } \\
\text { of it }\end{array}$ & $\begin{array}{l}\text { Janjić et al. (2019); Singh } \\
\text { and Singh (2012); Farris } \\
\text { et al. (2008) }\end{array}$ \\
\hline Insufficient implementation & This is related to insufficient & (2019); \\
\hline
\end{tabular}




\begin{tabular}{|c|c|c|}
\hline assistance & $\begin{array}{l}\text { assistance which is required during } \\
\text { KEs implementation }\end{array}$ & Stelson et al. (2017) \\
\hline $\begin{array}{l}\text { Insufficient } \\
\text { skills }\end{array}$ & $\begin{array}{l}\text { Leanings and skills of the } \\
\text { employees for the implementation } \\
\text { of KEs }\end{array}$ & $\begin{array}{l}\text { Stentoft and Freytag } \\
(2019) ; \text { Farris et al. } \\
(2008)\end{array}$ \\
\hline $\begin{array}{l}\text { Insufficient understanding } \\
\text { and perception of potential } \\
\text { benefits }\end{array}$ & $\begin{array}{l}\text { Lack of understanding about the } \\
\text { potential benefits of KEs } \\
\text { implementation among stakeholders }\end{array}$ & $\begin{array}{l}\text { Chan and Tay (2018); } \\
\text { Singh and Singh (2012); } \\
\text { Farris et al. (2008) }\end{array}$ \\
\hline Financial limitations & $\begin{array}{l}\text { This is related to the limitations of } \\
\text { the organisation to invest in KEs } \\
\text { activities }\end{array}$ & $\begin{array}{lcc}\text { Stentoft } & \text { and } & \text { Freytag } \\
(2019) ; & \text { Farris } & \text { et al. } \\
(2008) & & \end{array}$ \\
\hline Staff attitude & $\begin{array}{l}\text { Employees attitude related to KEs } \\
\text { implementation }\end{array}$ & $\begin{array}{l}\text { Janjić et al. (2019); Chan } \\
\text { and Tay (2018); Farris et } \\
\text { al. (2008) }\end{array}$ \\
\hline Organisational culture & $\begin{array}{l}\text { This refers to organisational } \\
\text { adaptability of new initiatives, i.e. } \\
\text { KEs implementation, etc. }\end{array}$ & $\begin{array}{l}\text { Nakamori et al. (2019); } \\
\text { Singh and Singh (2012); } \\
\text { Farris et al. (2008) }\end{array}$ \\
\hline $\begin{array}{l}\text { Backsliding to the old ways } \\
\text { of working }\end{array}$ & $\begin{array}{l}\text { Organisations do not want to change } \\
\text { their traditional working culture }\end{array}$ & $\begin{array}{l}\text { Stentoft and Freytag } \\
\text { (2019); Nakamori et al } \\
(2019)\end{array}$ \\
\hline Failure of past efforts & $\begin{array}{l}\text { This is related to the failure of past } \\
\text { efforts of the organisation when } \\
\text { implementing KEs }\end{array}$ & $\begin{array}{l}\text { Stentoft and } \text { Freytag } \\
(2019) ; \quad \text { Stelson et al. } \\
(2017) ; \text { Erdogan et al. } \\
(2017)\end{array}$ \\
\hline \multicolumn{3}{|c|}{ Implementation Stage } \\
\hline \multicolumn{3}{|c|}{$\begin{array}{l}\begin{array}{l}\text { Divergent Critical Successful Factors } \\
\text { implementation of KEs }\end{array} \\
\end{array}$} \\
\hline $\begin{array}{l}\text { Team member problem- } \\
\text { solving abilities }\end{array}$ & $\begin{array}{l}\text { This factor is related to team } \\
\text { members problem-solving abilities } \\
\text { that play a significant role in the } \\
\text { proper implementation of KEs }\end{array}$ & \begin{tabular}{llll} 
Janjić et al. & \multicolumn{2}{c}{ (2019); } \\
Gonzalez-Aleu et al, \\
$(2018) ; \quad$ Glover et al. \\
$(2014) ; \quad$ Farris et al. \\
$(2009)$
\end{tabular} \\
\hline $\begin{array}{l}\text { Functional and hierarchical } \\
\text { team heterogeneity }\end{array}$ & $\begin{array}{l}\text { Importance of functional and } \\
\text { hierarchical heterogeneity of teams } \\
\text { to implement KEs }\end{array}$ & $\begin{array}{l}\text { Janjić et al. (2019); } \\
\text { Glover et al. (2014) }\end{array}$ \\
\hline $\begin{array}{l}\text { Resourced support } \\
\text { (financial and non- } \\
\text { financial; i.e. equipment, } \\
\text { materials, } \\
\text { resources) }\end{array}$ & $\begin{array}{l}\text { This driver is related to the } \\
\text { significant role of resource support } \\
\text { (financial and non-financial) to KEs } \\
\text { implementation }\end{array}$ & 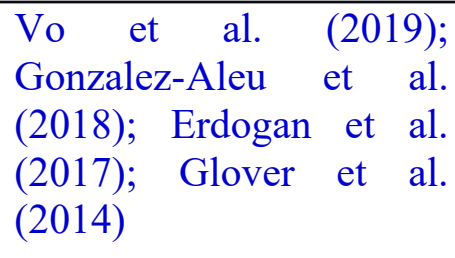 \\
\hline Event planning process & $\begin{array}{l}\text { Proper planning of the process } \\
\text { which is required to KEs } \\
\text { implementation }\end{array}$ & $\begin{array}{l}\text { Glover et al. (2014); } \\
\text { Farris et al. (2009); Farris } \\
\text { et al. (2008) }\end{array}$ \\
\hline $\begin{array}{l}\text { Systematic and strategic } \\
\text { KEs deployment }\end{array}$ & $\begin{array}{l}\text { A systematic and strategic KEs } \\
\text { deployment is a driving force to } \\
\text { KEs implementation }\end{array}$ & $\begin{array}{l}\text { Vo et al. (2019); Glover } \\
\text { et al. (2014); Farris et al. } \\
\text { (2009) }\end{array}$ \\
\hline \multicolumn{3}{|c|}{ Main barriers that organisations face during the implementation of KEs } \\
\hline Lack of management and & This barrier is related to the lack of & Janjić \\
\hline
\end{tabular}




\begin{tabular}{|c|c|c|}
\hline resource support & $\begin{array}{l}\text { management and resource support } \\
\text { to KEs implementation }\end{array}$ & $\begin{array}{l}\text { Erdogan et al. (2017); Liu } \\
\text { et al. (2015); Glover et } \\
\text { al. (2011) }\end{array}$ \\
\hline $\begin{array}{l}\text { Lack of well-defined and } \\
\text { thorough event planning }\end{array}$ & $\begin{array}{l}\text { This barrier is concerned with the } \\
\text { lack of a well-defined and thorough } \\
\text { event planning to KEs } \\
\text { implementation }\end{array}$ & $\begin{array}{l}\text { Janjić et al. (2019); Chan } \\
\text { and Tay (2018) }\end{array}$ \\
\hline $\begin{array}{l}\text { Lack of extensive event } \\
\text { planning }\end{array}$ & $\begin{array}{l}\text { This is related to the lack of } \\
\text { extensive event planning for KEs } \\
\text { implementation }\end{array}$ & $\begin{array}{l}\text { Nakamori et al (2019); } \\
\text { Glover et al. (2014); } \\
\text { Singh and Singh (2012); } \\
\text { Farris et al. (2009) }\end{array}$ \\
\hline Kamikaze strategy & $\begin{array}{l}\text { This is related to the existence of a } \\
\text { kamikaze strategy when } \\
\text { implementing KEs }\end{array}$ & $\begin{array}{l}\text { Abrosimov and } \\
\text { Mochalkin } \quad(2019) ; \\
\text { Glover et al. (2014); }\end{array}$ \\
\hline $\begin{array}{l}\text { Lack of performance } \\
\text { measurement }\end{array}$ & $\begin{array}{l}\text { This barrier is related to the lack of } \\
\text { performance measurement during } \\
\text { the proper implementation of KEs }\end{array}$ & $\begin{array}{l}\text { Erdogan et al. (2017); Liu } \\
\text { et al. (2015); Glover et } \\
\text { al. (2011) }\end{array}$ \\
\hline Lack of monitoring process & $\begin{array}{l}\text { A lack of proper monitoring process } \\
\text { that organisations face during the } \\
\text { implementation of KEs }\end{array}$ & $\begin{array}{l}\text { Vo et al. (2019); Kumar } \\
\text { et al. (2018); Van Aken } \\
\text { et al. (2010) }\end{array}$ \\
\hline $\begin{array}{l}\text { Lack of rewards and } \\
\text { recognition for team } \\
\text { members }\end{array}$ & $\begin{array}{l}\text { This barrier is related to the lack of } \\
\text { rewards and recognition to team } \\
\text { members who are playing an } \\
\text { important role during the } \\
\text { implementation of KEs }\end{array}$ & $\begin{array}{l}\text { Vo et al. (2019); Kumar } \\
\text { et al. (2018); Farris et al. } \\
(2009) ; \text { Farris et al. } \\
(2008)\end{array}$ \\
\hline $\begin{array}{l}\text { Lack of organisational } \\
\text { policies and procedures }\end{array}$ & $\begin{array}{l}\text { The lack of organisational policies } \\
\text { and procedures is also a major } \\
\text { barrier during the implementation of } \\
\text { KEs }\end{array}$ & $\begin{array}{l}\text { Abrosimov } \\
\text { Mochalkin (2019); Van } \\
\text { Aken et al. (2010); Farris } \\
\text { et al. (2008) }\end{array}$ \\
\hline \multicolumn{3}{|c|}{ Post-Implementation Stage } \\
\hline \multicolumn{3}{|c|}{ Main reasons that lead to unsuccessful KEs } \\
\hline $\begin{array}{l}\text { Insufficient team members' } \\
\text { problem-solving abilities }\end{array}$ & $\begin{array}{l}\text { This reason is related to the lack of } \\
\text { team member problem-solving } \\
\text { abilities that play a significant role } \\
\text { and which leads to unsuccessful } \\
\text { KEs }\end{array}$ & $\begin{array}{l}\text { Vo et al. (2019); Ueki et } \\
\text { al. (2019); Bortolotti et } \\
\text { al., (2018); Farris et al. } \\
\text { (2009) }\end{array}$ \\
\hline $\begin{array}{l}\text { Lack of functional and } \\
\text { hierarchical heterogeneity }\end{array}$ & $\begin{array}{l}\text { Lack of functional and hierarchical } \\
\text { heterogeneity of a team when } \\
\text { implementing them lead to } \\
\text { unsuccessful KEs }\end{array}$ & $\begin{array}{l}\text { Janjić et al. (2019); } \\
\text { Glover et al. (2014); } \\
\text { Farris et al. (2009) }\end{array}$ \\
\hline $\begin{array}{l}\text { Lack of resource support } \\
\text { (financial and } \text { non- } \\
\text { financial; i.e. equipment, } \\
\text { materials, } \\
\text { resources) }\end{array}$ & $\begin{array}{l}\text { This reason is related to the lack of } \\
\text { resources to KEs implementation. } \\
\text { This leads to unsuccessful KEs }\end{array}$ & $\begin{array}{l}\text { Vo et al. (2019); } \\
\text { Gonzalez-Aleu et al. } \\
(2018) ; \text { Erdogan et al. } \\
(2017)\end{array}$ \\
\hline $\begin{array}{l}\text { Excess or lack of event } \\
\text { planning process }\end{array}$ & $\begin{array}{l}\text { A lack of proper planning of the } \\
\text { process which is required to KEs } \\
\text { implementation leads to } \\
\text { unsuccessful KEs }\end{array}$ & $\begin{array}{l}\text { Lima et al. (2018); } \\
\text { Glover et al. (2014); } \\
\text { Farris et al. (2009); Farris } \\
\text { et al. (2008) }\end{array}$ \\
\hline
\end{tabular}




\begin{tabular}{|c|c|c|}
\hline $\begin{array}{l}\text { Lack of systematic and } \\
\text { strategic KEs deployment }\end{array}$ & $\begin{array}{l}\text { Lack of a systematic and strategic } \\
\text { KEs deployment is a driving force } \\
\text { which leads to unsuccessful KEs }\end{array}$ & $\begin{array}{l}\text { Vo et al. (2019); Glover } \\
\text { et al. (2014); Farris et al. } \\
(2009)\end{array}$ \\
\hline \multicolumn{3}{|c|}{ Main reasons that stopped organisations from running KEs } \\
\hline $\begin{array}{l}\text { Lack of leadership and } \\
\text { management support }\end{array}$ & $\begin{array}{l}\text { It is related to the lacking } \\
\text { commitment of leaders and } \\
\text { managers to KEs implementation } \\
\text { and how they link them with } \\
\text { business strategy and vision }\end{array}$ & $\begin{array}{l}\text { Vo et al. (2019); Oropesa } \\
\text { Vento et al. (2016); } \\
\text { Rivera-Mojica } \\
\text { Rivera-Mojica } \\
\text { García et al. (2013) }\end{array}$ \\
\hline $\begin{array}{l}\text { Lack of financial } \\
\text { capabilities support }\end{array}$ & $\begin{array}{l}\text { Lack of financial investment that } \\
\text { stopped organisations from running } \\
\text { KEs }\end{array}$ & $\begin{array}{l}\text { Vo et al. (2019); Erdogan } \\
\text { et al. (2017); García- } \\
\text { Alcaraz et al. (2013) }\end{array}$ \\
\hline $\begin{array}{l}\text { Inappropriate } \\
\text { organisational culture }\end{array}$ & $\begin{array}{l}\text { This is related to an inappropriate } \\
\text { organisational which does not } \\
\text { support CI and hence KEs }\end{array}$ & $\begin{array}{l}\text { Vo et al. (2019); Janjić et } \\
\text { al. (2019) }\end{array}$ \\
\hline $\begin{array}{l}\text { Negative employees' } \\
\text { attitude towards KEs }\end{array}$ & $\begin{array}{l}\text { Negative employees' attitude } \\
\text { towards KEs is one of the reasons } \\
\text { which play an important negative } \\
\text { role in their implementation }\end{array}$ & 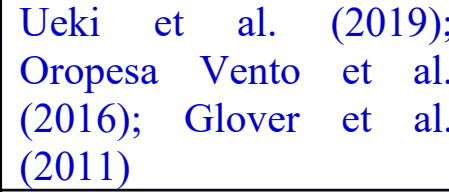 \\
\hline $\begin{array}{l}\text { Lack of organisational } \\
\text { policies and procedures }\end{array}$ & $\begin{array}{l}\text { This is related to the lack of } \\
\text { organisational policies and } \\
\text { procedures which are required to } \\
\text { support KEs }\end{array}$ & $\begin{array}{l}\text { Ueki et al. (2019); } \\
\text { Stelson et al. (2017); } \\
\text { Glover et al. (2011) }\end{array}$ \\
\hline $\begin{array}{l}\text { Lack of systematic and } \\
\text { strategic KEs }\end{array}$ & $\begin{array}{l}\text { This factor is related to the lack of } \\
\text { systematic and strategic KEs } \\
\text { procedures which are essential to } \\
\text { support their deployment }\end{array}$ & $\begin{array}{l}\text { Kumar et al. (2018); } \\
\text { Cavazos-Arroyo et al. } \\
\text { (2018); Glover et al. } \\
(2011)\end{array}$ \\
\hline $\begin{array}{l}\text { Lack of appropriate } \\
\text { progress monitoring }\end{array}$ & $\begin{array}{l}\text { This factor is related to the lack of } \\
\text { appropriate progress monitoring to } \\
\text { support KEs }\end{array}$ & $\begin{array}{l}\text { Cavazos-Arroyo et al. } \\
\text { (2018); Liu et al. (2015); } \\
\text { Van Aken et al. (2010) }\end{array}$ \\
\hline $\begin{array}{l}\text { Lack of appropriate } \\
\text { performance measurements }\end{array}$ & $\begin{array}{l}\text { This factor is related to the lack of } \\
\text { appropriate performance } \\
\text { measurements to support KEs }\end{array}$ & $\begin{array}{l}\text { Dresch et al. (2019); } \\
\text { Kumar et al. (2018); Liu } \\
\text { et al. (2015) }\end{array}$ \\
\hline $\begin{array}{lcr}\text { Lack of } & \text { rewards } \\
\text { recognition } & \text { for } & \text { team } \\
\text { members } & & \end{array}$ & $\begin{array}{l}\text { This factor is related to the lack of } \\
\text { rewards and recognition to team } \\
\text { members which are required to } \\
\text { support KEs }\end{array}$ & $\begin{array}{l}\text { Janjić et al. (2019); } \\
\text { Dresch et al. (2019); } \\
\text { Erdogan et al. (2017); Liu } \\
\text { et al. (2015) }\end{array}$ \\
\hline
\end{tabular}

\subsection{Research Gaps}

The implementation of KEs has significantly increased in recent years (Chan and Tay 2018). KEs implementation can be divided into three stages: pre-implementation, implementation and post-implementation. As any other LM tool, KEs must be properly planned in the preimplementation stage to identify difficulties in the deployment process that need to be overcome (García-Alcaraz et al. 2017a). After doing an extensive literature review, we concluded that there is extensive literature available on the Kaizen philosophy (Kumar et al. 2018b; Singh and Singh 2009). However, despite its popularity, KEs implementation in companies had little success 
(Cannas et al. 2018; García-Alcaraz et al. 2013). Thus, there is a need to not only understand KEs but also the methods and factors that affect their implementation (Mitra Debnath 2019). Nevertheless, there is a lack of studies on the design, implementation and outcomes of KEs (Gonzalez-Aleu et al. 2018; Awad and Shanshal 2017; Natale et al. 2013).

Although the majority of organisations find it difficult to sustain even half of the desired results after the deployment of improvement initiatives (Ferreira and Saurin 2019), previous investigators have mainly focused only on successful cases of KEs, paying less attention to nonsuccessful cases. Taking into consideration these limitations, the authors highlight the need of investigating less successful KEs, as the comprehension of such cases is critical for organisational learning (Farris et al. 2008; Sitkin 1992; Cole 1992). Thus, further researches are still needed in this field (Awad and Shanshal 2017).

Organisations consist of people, therefore, studying and understanding unsuccessful, or less successful, KEs will contribute not only to organisational learning and growth but also theoretically and practically to the body of knowledge regarding KEs and their optimised utilisation for achieving improvements in organisational performance. It is to the best of our knowledge that no such study exists that considers the pre-implementation, implementation and post-implementation stages when deploying KEs. Therefore, the present research addresses gaps in the current literature by addressing these phases (i.e. pre-implementation, implementation and post-implementation) of KEs implementation.

\section{Research Methodology}

This section discusses the overall research procedure followed in this study. A systematic methodological flow, which steps are recommended by various authors (Field 2017; Sekaran and Bougie 2016; Hair et al. 2013) and have been used by several researchers (Tortorella et al. 2020; Zailani et al. 2017; Luthra et al. 2015), was employed to achieve the objectives of this study. Figure 1 illustrates the research methodology framework of the study. 
Figure 1. Research methodology framework of the study

As per the given framework, first, an extensive literature review on managerial aspects of KEs implementation was conducted and RQs developed as per the research objectives of the study. A survey questionnaire was then designed and a pilot test conducted. After the completion of the questionnaire, data were collected from the manufacturing sector. Based on their feedback, the questionnaire was amended to exclude participants' errors and bias as follows:

\subsection{Questionnaire Design}

The objective of the presented study consisted of investigating various managerial aspects of KEs through six RQs as illustrated in Figure 1. For this reason, a number of experts in lean and business excellence who had experience preparing and deploying KEs and that were dispersed around the world were consulted. To collect primary data from these experts, a survey questionnaire was designed (Field 2017; Fowler 2013; Harkness et al. 2004). The instrument was 
constructed using Qualtrics software as experts could easily access it via various mobile devices and web browser, and due to the results could be directly migrated into an Excel spread-sheet to facilitate their import to specialised statistical software, e.g. SPSS 21.0.

Due to the nature of the designed questions, data were collected, facilitating their statistical analysis (Black 2019; Binti Aminuddin et al., 2016). The questionnaire instrument included twenty questions that were generated based on the RQs formulated through the literature review. The questions, and their applicable choices, were generated by combining the results obtained from the literature and the lessons learnt obtained from it as well as the industrial experience of the authors. Table A1, see Appendix A, presents the questionnaire, while Figure 2 shows the systematic thinking process behind the questionnaire's development.

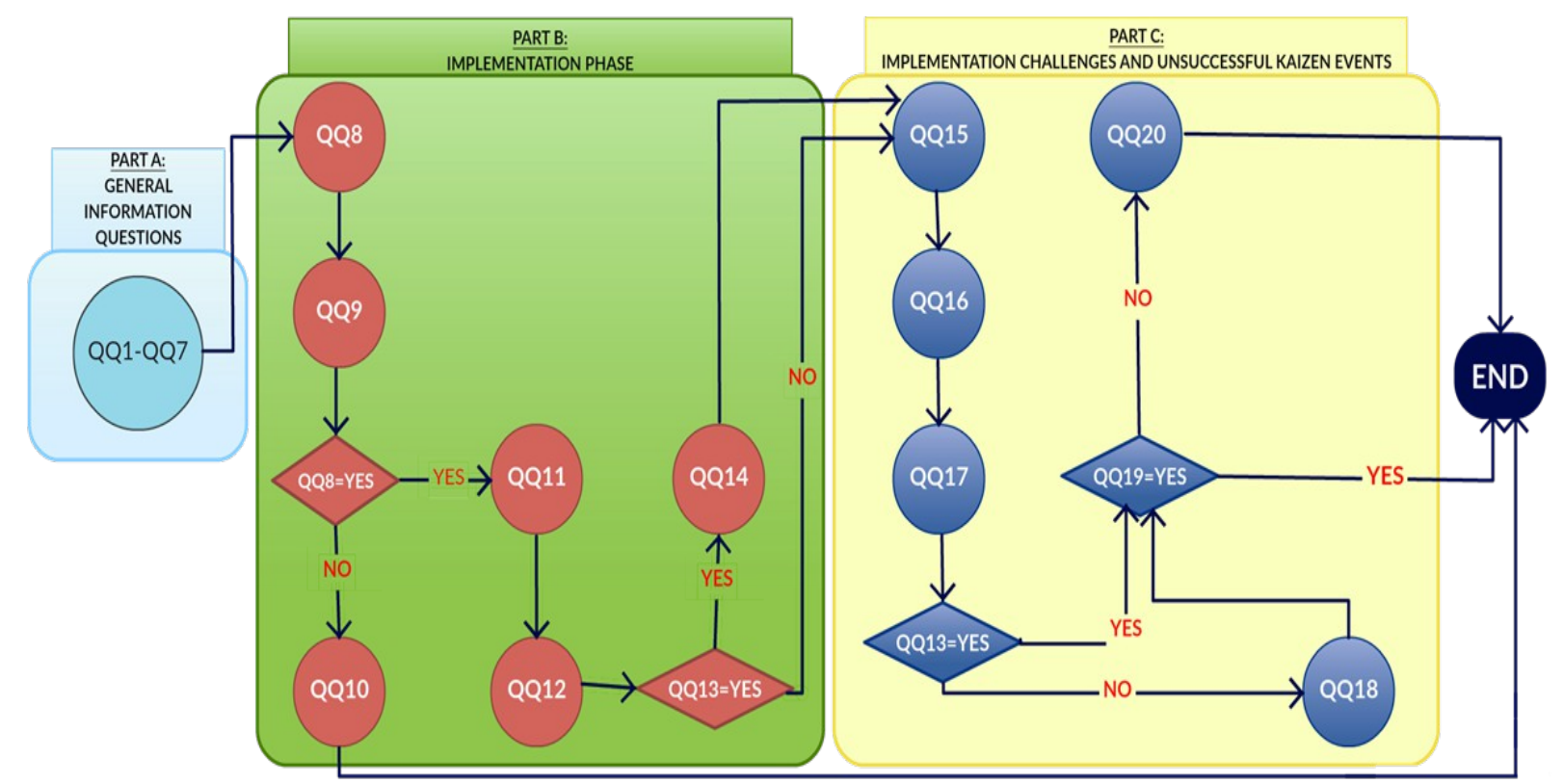

Figure 2. Questionnaire's logic

\subsection{Testing and Completion of the Questionnaire}

Four reliability threats related to subject or participant are commonly recognised as a challenge to overcome during the design of questionnaires, namely: bias, error, and observer bias (Hair et al. 2013; Robson 2011). To overcome these challenges and confirm the questionnaire's validity and reliability, a pilot study was conducted (Sekaran and Bougie 2016; Robson 2011). For the present research, the questionnaire was distributed among 4 academics and 3 industrial experts.

- Their feedback contributed to proving further comprehensiveness and clarification in some of the questions;

- The questions were revised in terms of their quantity and relationship to RQs in order to make sure that these could be respectively tested and addressed. 
Observer bias and error were not applicable due to the questionnaire was based on fixedalternative questions that did not require interpretation (Andreadis et al. 2017; Hair et al. 2013).

\subsection{Sample Selection and Size}

The main objective of the study was to investigate the various managerial aspects that have an effect on the implementation of KEs across different stages. Therefore, the target population for data collection were experts from businesses which had expertise in the research subject. Thus, it was decided that manufacturing organisations would be considered the focus of the study and hence data collection. It was of paramount importance to collect data from experts who had practical and/or research experience in the field. Based on these criteria, junior and senior managers, team leaders, team members, directors, specialists and consultants were contacted. In the literature, different criteria are given by researchers in regards to sample size (Field 2017; Hair et al. 2013), but the minimum and maximum sample size depend on the specific situation. In this study, 175 was the sample size employed, which is comparable to other similar studies in the field (Tortorella et al. 2020; Piyathanavong et al. 2019; Andreadis et al. 2017).

\subsection{Data Collection}

Since the present study was of an exploratory nature, the questionnaire was circulated to respondents within the manufacturing sector worldwide. It was distributed through the Internet, mainly via social media, e.g. LinkedIn (Roopa and Rani 2012). Particularly, the questionnaire was posted, with a cover letter that described the nature and purpose of the research, on 15 group societies in LinkedIn related to LM and KEs. Furthermore, questionnaires were also circulated via email to the personal contacts of the authors. The contacts were also asked to distribute forward the questionnaire to their own relevant networks as a strategy to increase the number of potential respondents (Horwitz et al. 2006).

The questionnaire's distribution strategy allowed the collection of 183 responses from junior and senior managers, team leaders, team members, directors, specialists, consultants and interns.

\subsection{Data Preparation and Screening}

During the screening process, it was found that a small number of respondents, i.e. 8, did not comply with this criterion and hence these were dropped from the data set. For this reason, 175 was the sample size employed to conduct the descriptive and inferential analyses presented in the subsequent sections. Stemming from comparative response rates and LM studies such as those of Andreadis et al. (2017), Binti Aminudin et al. (2016) and Belekoukias et al. (2014) among 
others, the sample size of 175 responses was considered adequate (Field 2017; Hair et al. 2013) to draw some initial conclusions regarding the managerial aspects of KEs investigated. The profile of the respondents, and their companies, in reference to their position and lean's experience as well as their company's manufacturing sector, geographical location and size are presented in Table 3.

Table 3. Respondents and their companies' profile

\begin{tabular}{|c|c|c|c|}
\hline Company Size & & Region & \\
\hline Large $(>250)$ & $79.4 \%$ & Europe & $36.6 \%$ \\
\hline Medium (50-250) & $19.4 \%$ & Asia & $19.4 \%$ \\
\hline Small $(<50)$ & $1.1 \%$ & North America & $18.3 \%$ \\
\hline & & Africa & $11.4 \%$ \\
\hline Manufacturing Sector & & Australia & $8.6 \%$ \\
\hline Automotive & $32 \%$ & South America & $5.7 \%$ \\
\hline Electronics & $19.4 \%$ & & \\
\hline Chemical & $7.4 \%$ & Respondent's Position & \\
\hline Metal \& Steel & $6.3 \%$ & Manager & $42.3 \%$ \\
\hline Textiles, Leather and Apparel & $5.7 \%$ & Team Leader & $30.9 \%$ \\
\hline Petroleum, Coal and Plastics & $5.7 \%$ & Senior Manager & $17.7 \%$ \\
\hline Aerospace & $5.7 \%$ & Team Member & $5.1 \%$ \\
\hline Fast Moving Consumer Goods & $4.0 \%$ & Director & $2.3 \%$ \\
\hline Defence & $3.4 \%$ & Specialist & $0.6 \%$ \\
\hline Food and Beverages & $2.3 \%$ & Consultant & $0.6 \%$ \\
\hline Medical Devices & $1.7 \%$ & Intern & $0.6 \%$ \\
\hline Mining & $1.1 \%$ & Managing Director & $0 \%$ \\
\hline Paper & $1.1 \%$ & & \\
\hline Biomedical & $0.6 \%$ & Lean Experience of Participants & \\
\hline Finance & $0.6 \%$ & 10 Years or more & $32.6 \%$ \\
\hline Toys & $0.6 \%$ & 5-10 Years & $43.4 \%$ \\
\hline Ceramics & $0.6 \%$ & $2-5$ Years & $18.9 \%$ \\
\hline Heavy Industry & $0.6 \%$ & Less than 2 Years & $4.6 \%$ \\
\hline Construction & $0.6 \%$ & No Experience & $0.6 \%$ \\
\hline Transport \& Logistics & $0.6 \%$ & & \\
\hline
\end{tabular}

\subsection{Reliability and Validity of the data}

The collection of data was based on the variables included in Table 1. Reliability tests help to measure the 'goodness' of the collected data from the respondents (Sekaran and Bougie 2016). 
Several types of reliability tests exist, for instance, internal consistency, test-retest, split-half and homogeneous, etc. (Sekaran and Bougie 2016; Cronbach 1951). In this study, a test for internal consistency reliability was conducted by using the Cronbach Alpha coefficient (Nunnally, 1978). Nunnally (1978) and Nunnally and Bernstein (1994) suggests that Cronbach's alpha ( $\alpha$ ) is a commonly used tool to assess the reliability of a Likert scale-based data set. The factor-loading concept helps to check convergent validity; if the value obtained is greater than 0.5 , then the scale is said to have convergent validity (Field 2017). Therefore, in this study, we used Cronbach's alpha $(\alpha)$ and its recommended values by Nunnally and Bernstein (1994) as well as the factors loading of each variable (Field 2017).

As per the objectives of the study, the first objective was to identify and evaluate the drivers and barriers in the pre-implementation stage of KEs. Therefore, the main drivers and barriers to the utilisation of KEs were identified. As the scale of these questions was nominal, the frequency of each variable was calculated by using descriptive statistics. However, to achieve the remaining two objectives, i.e. to identify and evaluate the CSFs and barriers in the implementation stage of KEs and to evaluate the reasons in the post-implementation stage that lead to unsuccessful KEs and those that force companies to stop running them, Cronbach's alpha $(\alpha)$ and factors loading tests were followed. As per the questionnaire's logic shown in Figure 2, the data for these phases were collected based on a 5-point Likert scale from "Not at all important (1)" to "Extremely important (5)". The reliability and validity of the data are shown in Table 4.

Table 4. Reliability and validity of the data

\begin{tabular}{|c|c|c|c|}
\hline Statements & $\begin{array}{c}\text { Corrected } \\
\text { Item-Total } \\
\text { Correlation } \\
\end{array}$ & $\begin{array}{l}\text { Single- } \\
\text { factor } \\
\text { loading }\end{array}$ & $\begin{array}{c}\text { Overall } \\
\text { Cronbach's } \\
\text { alpha }(\alpha) \\
\end{array}$ \\
\hline Team member problem-solving abilities & 0.601 & 0.721 & \multirow{5}{*}{0.857} \\
\hline $\begin{array}{l}\text { Functional and hierarchical heterogeneity of } \\
\text { team }\end{array}$ & 0.646 & 0.758 & \\
\hline $\begin{array}{l}\text { Resource support (financial and non-financial; } \\
\text { i.e. equipment, materials, human resources) }\end{array}$ & 0.771 & 0.893 & \\
\hline Event planning process & 0.771 & 0.893 & \\
\hline $\begin{array}{l}\text { Systematic and strategic Kaizen Events } \\
\text { deployment }\end{array}$ & 0.616 & 0.745 & \\
\hline Lack of management and resource support & 0.609 & 0.701 & \multirow{5}{*}{0.885} \\
\hline $\begin{array}{l}\text { Lack of well-defined and thorough event } \\
\text { planning }\end{array}$ & 0.678 & 0.767 & \\
\hline Lack of extensive event planning & 0.686 & 0.769 & \\
\hline Kamikaze strategy & 0.740 & 0.811 & \\
\hline Lack of performance measurement & 0.601 & 0.680 & \\
\hline
\end{tabular}




\begin{tabular}{l|c|c|c|}
\hline Lack of monitoring process & 0.600 & 0.792 & 0.766 \\
\hline $\begin{array}{l}\text { Lack of rewards and recognition for team } \\
\text { members }\end{array}$ & 0.667 & 0.763 & \\
\hline Lack of organisational policies and procedures & 0.680 & 0.788 & \\
\hline $\begin{array}{l}\text { Insufficient team members problem-solving } \\
\text { abilities }\end{array}$ & 0.651 & 0.790 \\
\hline $\begin{array}{l}\text { Lack of functional and hierarchical } \\
\text { heterogeneity }\end{array}$ & 0.645 & 0.846 \\
\hline $\begin{array}{l}\text { Lack of resource support (financial and non- } \\
\text { financial; i.e. equipment, materials, human } \\
\text { resources) }\end{array}$ & 0.626 & \\
\hline Excess or lack of event planning process & 0.630 & 0.762 \\
\hline $\begin{array}{l}\text { Lack of systematic and strategic Kaizen Events } \\
\text { deployment }\end{array}$ & 0.700 & 0.810 & \\
\hline Lack of leadership and management support & 0.625 & 0.708 & \\
\hline Lack of financial capabilities support & 0.639 & 0.719 \\
\hline Inappropriate organisational culture & 0.643 & 0.723 \\
\hline Negative employees' attitude towards KEs & 0.759 & 0.824 \\
\hline Lack of organisational policies and procedures & 0.693 & 0.770 \\
\hline Lack of systematic and strategic KEs & 0.684 & 0.759 \\
\hline Lack of appropriate progress monitoring & 0.667 & 0.747 \\
\hline Lack of appropriate performance measurements & 0.681 & 0.757 \\
\hline $\begin{array}{l}\text { Lack of rewards and recognition for team } \\
\text { members }\end{array}$ & 0.646 & 0.725 \\
\hline
\end{tabular}

Cronbach's alpha $(\alpha)$ is a coefficient of reliability (or consistency). Using reliability analysis, the overall Cronbach's alpha $(\alpha)$ was calculated and its value resulted $>0.80$ as recommended in the literature (Field 2017; Hair et al. 2013; Cronbach, 1951), see Table 4. Gliem and Gliem (2003) suggested that the corrected item-total correlation among items is also appropriate to show the descriptive information about the correlation of each item with the sum of all remaining items. The value of the corrected item-total correlation was $>0.60$, which indicated consistency among the items (Gliem and Gliem, 2003). To check convergent validity of each variable to the construct, single item factor loading was calculated by applying exploratory factor analysis, which resulted $>0.65$, and hence was considered acceptable (Field 2017; Hair et al. 2013). These values indicated the reliability and convergent validity of the data (Field 2017; Sekaran and Bougie 2016; Hair et al. 2013).

\section{Analysis and Results}

In this section, the analysis of various identified variables to utilise KEs and their related results are provided. 


\subsection{Analysis of Pre-Implementation Stage of KEs}

As per the first objective of the study, i.e. to identify and evaluate the drivers and barriers in the pre-implementation stage of KEs, RQ1 and RQ2 were formulated and questions were included in the questionnaire, as shown in Appendix 1, for data collection. Data collection was based on the variables indicated in Table 2.

From the 175 responses, $140(80 \%)$ companies had implemented KEs (QQ8) while 168 (97.1\%) had deployed LM or any other lean method (e.g. JIT, TPM, VSM, Jidoka/Autonomation, etc.) (QQ9). Figure 3(a) presents the main drivers that led the surveyed organisations to utilise KEs (RQ1). Additionally, Figure 3(b) does the same, but in this case, for the main barriers that made some of the organisations not to implement KEs (RQ2).

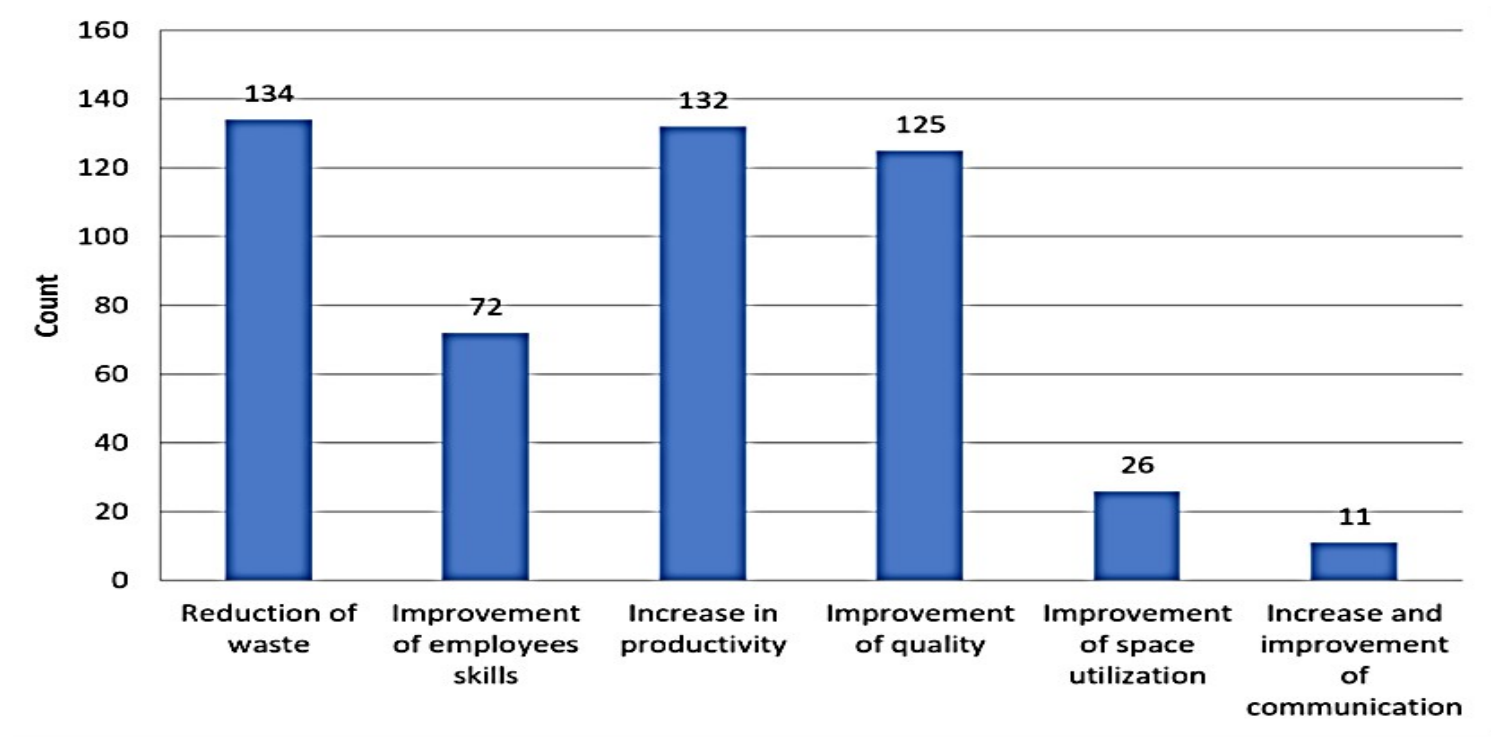

(a) 


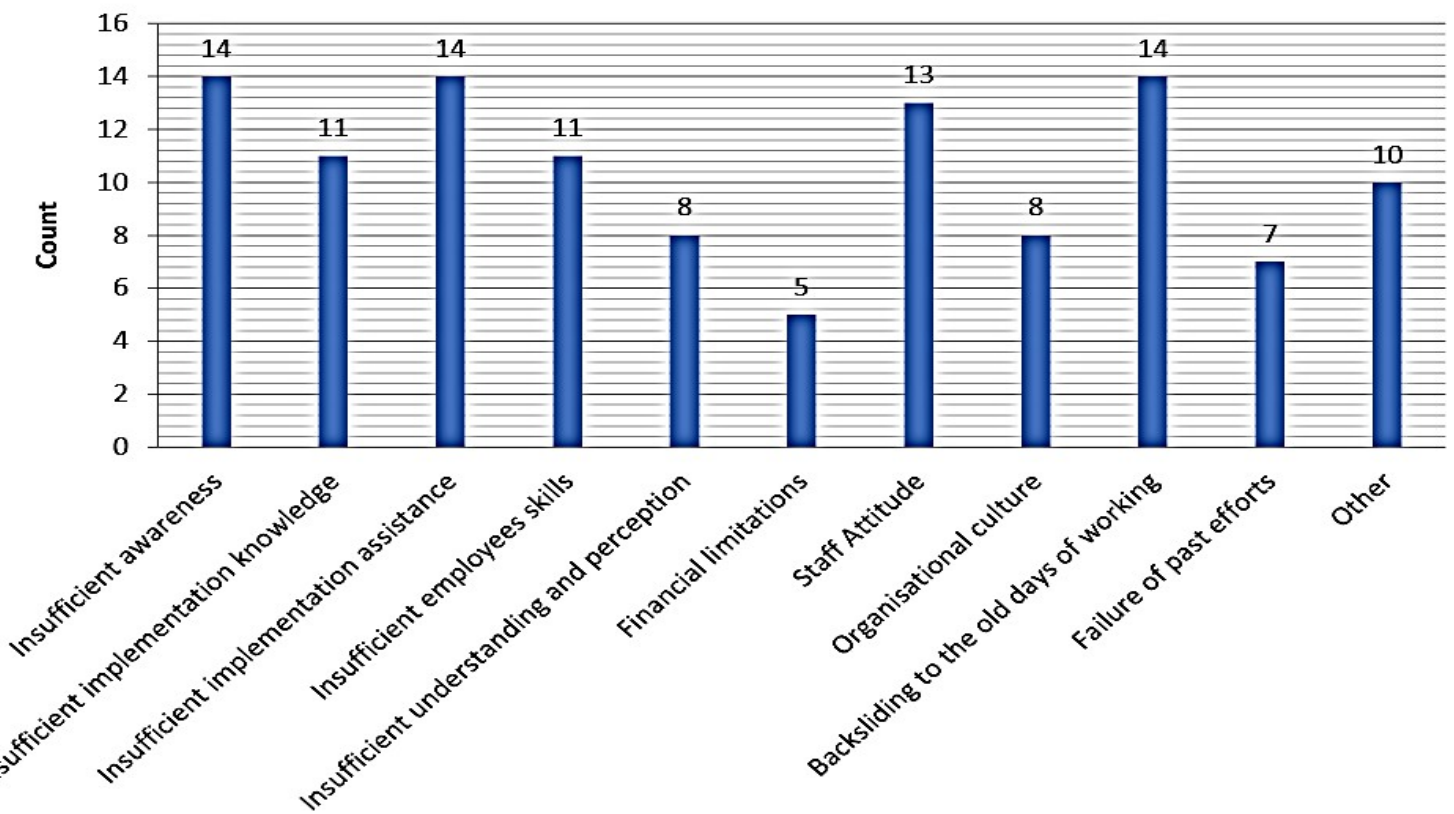

(b)

Figure 3. (a) Drivers and (b) Barriers to the implementation of KEs

Regarding the drivers (RQ1), 'Reduction of waste' and 'Increase in productivity' were identified as the most significant factors that led organisations to implement KEs, followed by 'Improvement of quality', see Figure 3(a). Figure 3(b) illustrates the main reasons that contributed to the lack of KEs implementation in the organisations studied (RQ2). 'Insufficient awareness', 'Insufficient implementation assistance' and 'Backsliding to the old ways of working' were identified as the main barriers that made the studied organisations not to implement KEs.

\subsection{Analysis of Implementation Stage of KEs}

As per the second objective of the study, i.e. to identify and evaluate the Critical Successful Factors (CSFs) and barriers in the implementation stage of KEs, RQ3 and RQ4 were formulated and questions were included in the questionnaire for data collection as suggested in Appendix 1. RQ3 was addressed with the sample of 140 (80\%) companies that had implemented KEs. The results are presented in Figure 4, showing the most significant divergent CSFs for the effective implementation of KEs. 


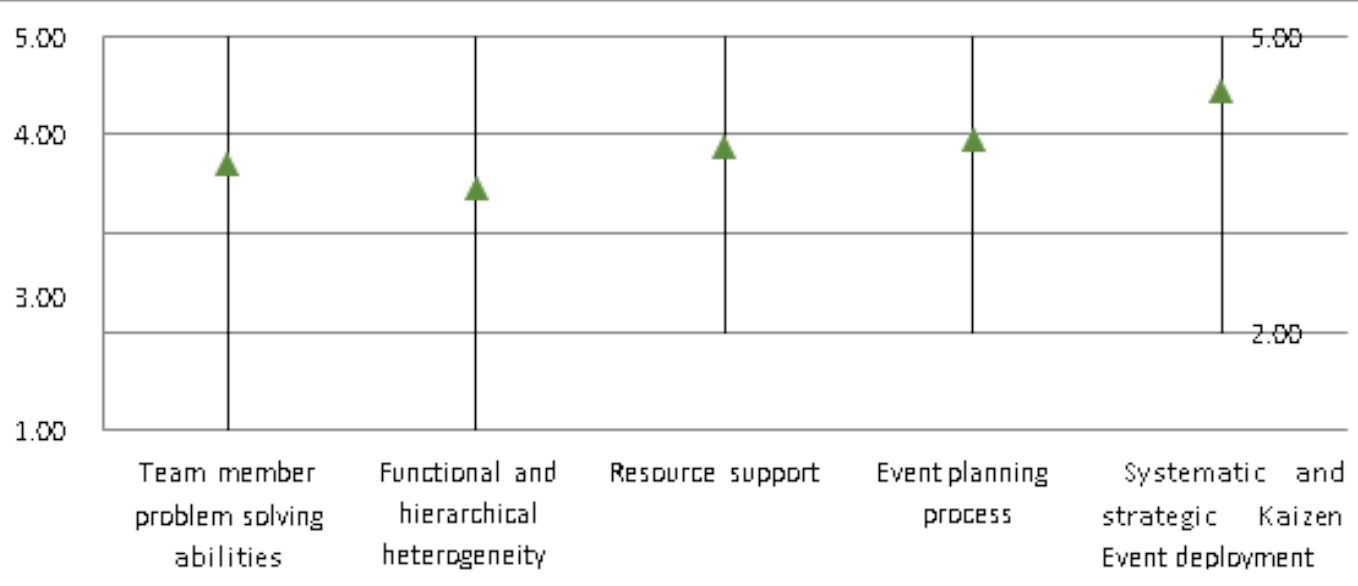

Factor is

Figure 4. Importance of CSFs for the implementation of Kaizen Events

Furthermore, a one-way ANOVA was conducted to validate the significance of the results, see Table 5.

Table 5. One-way ANOVA

Summary-Single Factor ANOVA

\begin{tabular}{|l|c|c|c|c|}
\hline Groups & $\begin{array}{c}\text { Coun } \\
\mathbf{t}\end{array}$ & Sum & Average & Variance \\
\hline Team member problem solving abilities & 140 & 519.08 & 3.71 & 0.676 \\
\hline Functional and hierarchical heterogeneity & 140 & 487.69 & 3.48 & 1.267 \\
\hline Resource support & 140 & 545.91 & 3.89 & 0.891 \\
\hline Event planning process & 140 & 551.06 & 3.92 & 0.721 \\
\hline Systematic and strategic KEs development & 140 & 614.61 & 4.39 & 0.554 \\
\hline
\end{tabular}

ANOVA

\begin{tabular}{|l|c|c|c|c|c|c|}
\hline Source of Variation & $\boldsymbol{S S}$ & $\boldsymbol{d f}$ & $\boldsymbol{M S}$ & $\boldsymbol{F}$ & p-value & $\boldsymbol{F}$ crit \\
\hline Between Groups & 63.072 & 4 & 15.77 & 19.66 & $2.39 \mathrm{E}-15$ & 2.384 \\
\hline Within Groups & 557.258 & 695 & 0.801 & & & \\
\hline Total & $\mathbf{6 2 0 . 3 3 0}$ & $\mathbf{6 9 9}$ & & & & \\
\hline
\end{tabular}

As indicated by the ANOVA, at a significance level of $\alpha=0.05$, the results showed a statistical difference between the means of the divergent CSFs ( $p$-value $\leq 0.05)$, indicating that 
these have different effects on the implementation of KEs. As indicated by the descriptive analysis and means in the ANOVA test, a 'Systematic and strategic Kaizen Event development' is considered the most important divergent CSF, followed by 'Event planning process' and 'Resource support'.

The results presented in Figure 5 show the main barriers found to hinder the implementation of KEs.

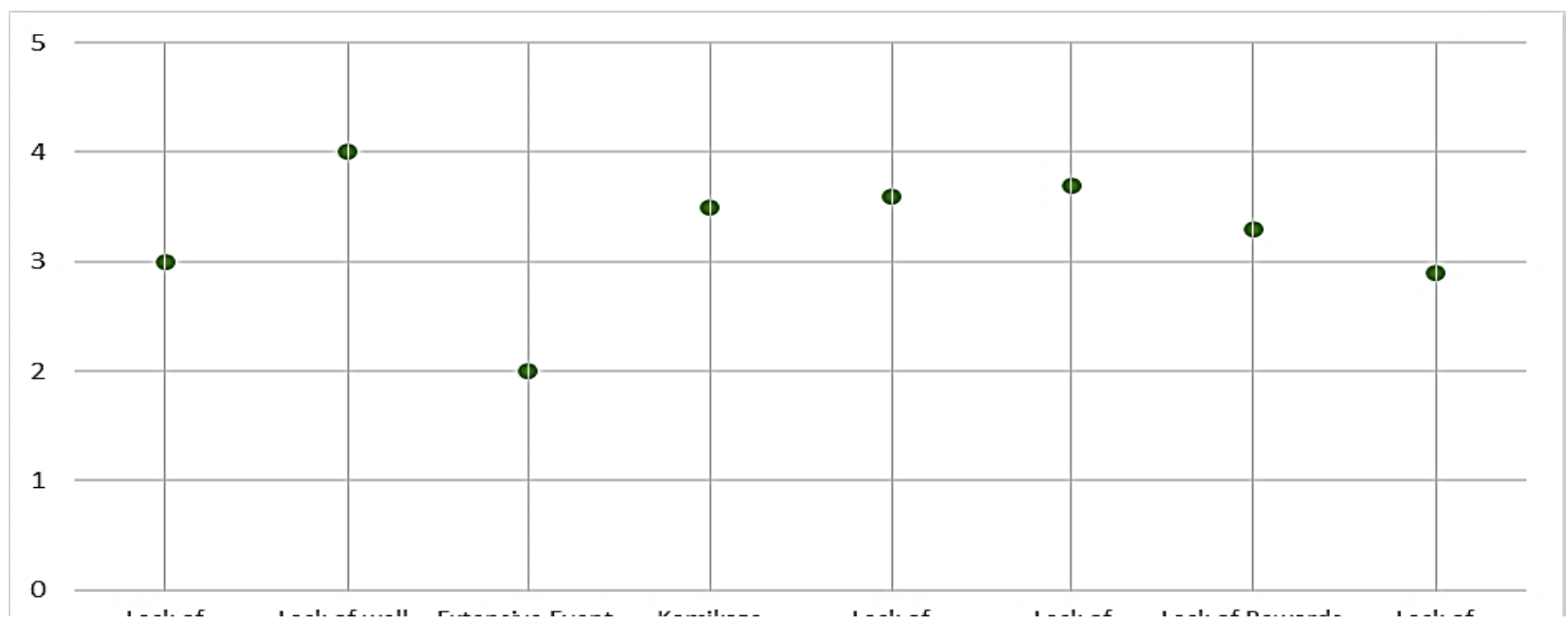

Figure 5. Barriers to the implementation of KEs

As indicated and as aligned to RQ3, a 'Well-defined and thorough event planning' is considered the most important CSF for the implementation of KEs. So, its absence is also considered the most significant barrier for such implementation, see Figure 5 as per RQ4. The following two most important barriers included 'Lack of monitoring process' and 'Lack of performance measurement'.

\subsection{Analysis of Post-Implementation Stage of KEs}

The success and sustainment of operational improvement efforts are governed by various CSFs that are required to be fulfilled. The same principle applies to KEs, which require some factors and characteristics to be enabled to ensure their success. Therefore, to achieve the third objective of the study, i.e. to evaluate the reasons in the post-implementation stage that lead to unsuccessful KEs and those that force companies to stop running them, RQ5 and RQ6 were formulated.

The value analysis $(\beta=0.428, t=7.386, p<0.01)$ suggested that the alignment of KEs with improvement programmes and the overall business strategy will significantly influence the success of such events. Improvement programmes are considered to enhance performance strategies that support the overall strategy of organisations while, on the other hand, KEs may be 
seen as a lower level strategy and platform for the operationalisation of such strategies. In this context, the results obtained from this study corroborate the well-established principle that in order for businesses to be successful, their strategies need to be characterised by a close alignment, e.g. in terms of purpose, operationalisation, among other factors.

'Lack of systematic and strategic Kaizen events' and 'Insufficient members problem-solving abilities' were reported as two main factors leading to the unsuccessful implementation of KEs as per RQ6. Nevertheless, despite a close association between KEs with improvement programmes, the overall strategy of companies is fundamental for their attainment, other factors may also contribute to their failure, see Figure 6.

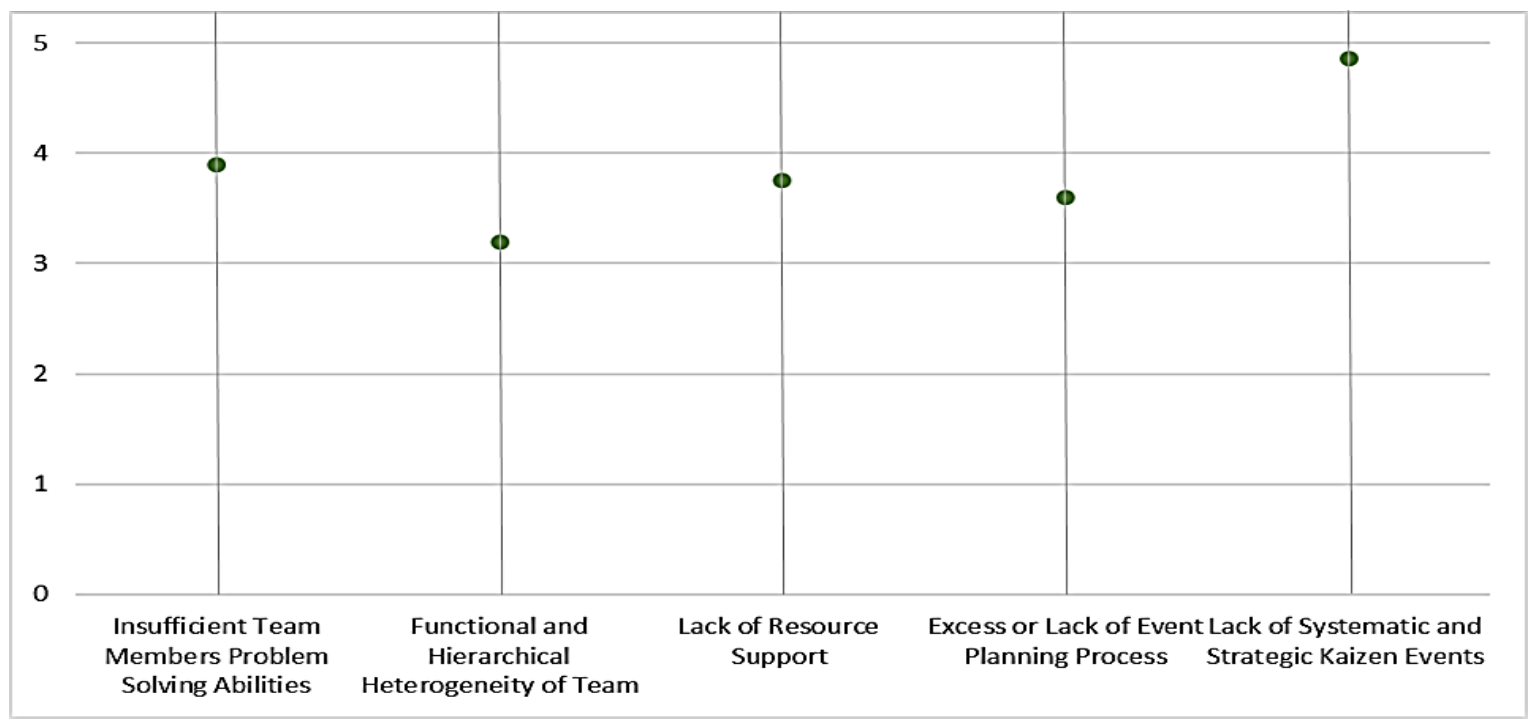

Figure 6. Factors leading to the unsuccessful implementation of KEs

Successful organisations are characterised by the sustainment of improvement efforts and initiatives. KEs are an improvement mechanism associated with LM, it runs the risk of being a strategy that is initially deployed to drive improvements in an organisation but then abandoned due to various circumstances. This study found that out of the 140 organisations that had implemented KEs, 18 of them had discontinued their efforts. Figure 7 presents some of the reasons that led to this phenomenon. 


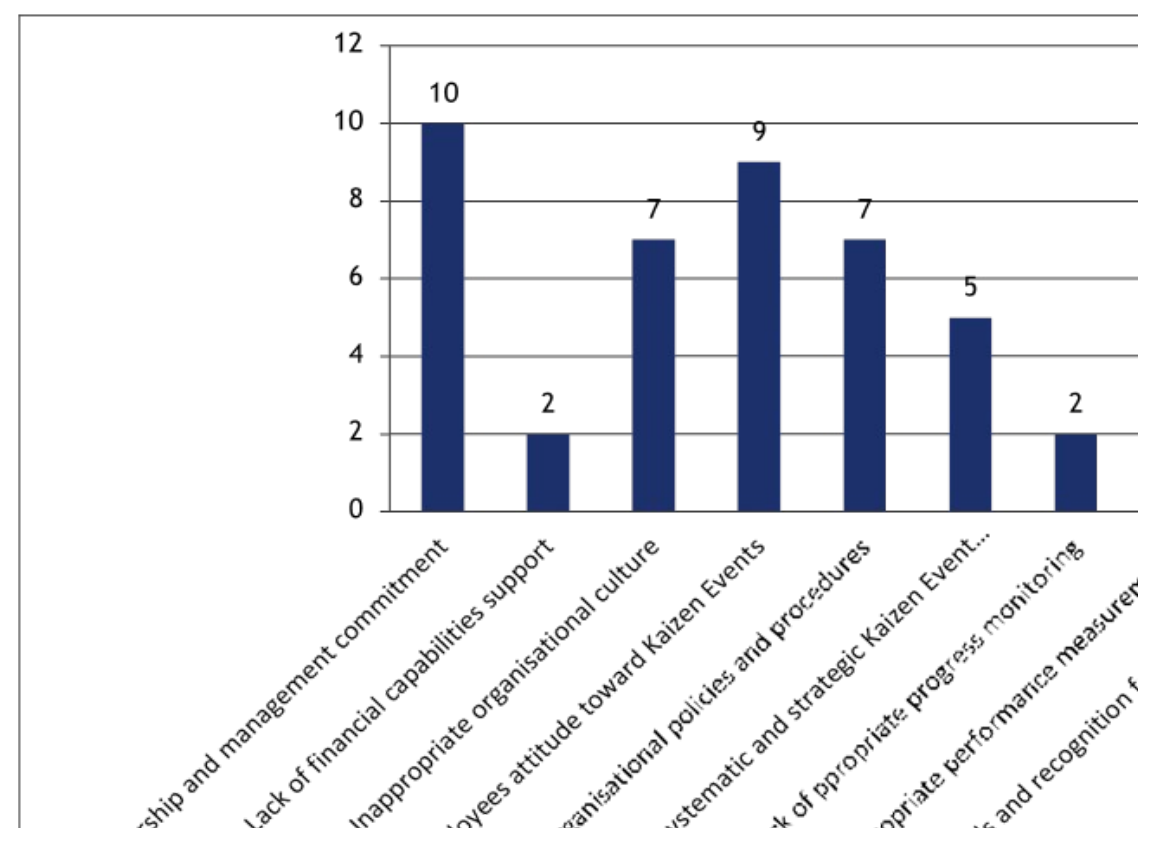

Figure 7. Reasons for organisations abandoning Kaizen Events

'Lack of leadership and management' is reported as one of the key reasons for organisations abandoning KEs. On the other hand, employees positive or negative attitudes will have an effect on improvement efforts and hence their sustainment. This factor, according to the results of the present study, has been an important reason as to why the studied companies stopped KEs. Overall, these results suggest that similarly as other improvement initiatives, KEs are prompted to be abandoned if various factors, see Figure 7, are not effectively addressed through company policies aimed at their reduction/elimination.

\section{Discussion of Findings}

This study has investigated the implementation of KEs in different stages to identify and evaluate the drivers, barriers in the pre-implementation; the critical success factors and barriers in the implementation; and assess the reasons in the post-implementation stage that lead to unsuccessful KEs and those that force companies to stop running them. Thus, this study contributes to the contingency and RBV theories. The contingency theory suggests that the optimal course of action is dependent upon internal and external situations (Scott, 1981) while the RBV determines the strategic resources a firm can exploit to achieve a sustainable competitive advantage (Barney, 1991). Through this investigation, the findings of the study provide insights to industry managers for the effective implementation of KEs in different stages, 
which can help them to enhance the competitive advantage and resources utilisation of their organisations.

The findings of the study show that 'Reduction of waste' and 'Increase in productivity' were identified as the most significant drivers that led organisations to implement KEs, followed by 'Improvement of quality' as shown by Figure 3(a). The findings align to the positive technical outcomes, in terms of performance, that are considered as main drivers of KEs implementation by Manos (2007) and Farris et al. (2006). Particularly, Manos (2007) argues that KEs focus on waste reduction and the overall improvement of productivity, whereas Kaizen, as a broader longterm philosophy, is mainly used to achieve any benefit, including improving the quality of worklife. Thus, the outcome of the descriptive statistical-based analysis' of the present study contributes to the contingency theory by offering an understanding of the significance of drivers that lead organisations to implement KEs. This can help and support organisations in determining where to focus and how to minimise waste as well as improving productivity and quality through the implementation of KEs.

Figure 3(b) illustrates that 'Insufficient awareness', 'Insufficient implementation assistance' and 'Backsliding to the old ways of working' were identified as the main barriers that made the studied organisations not to implement KEs. This may be the reason why the improvement of employees' skills and the increase and improvement of communication, which are considered as positive social outcomes and relate to the quality of work-life, were lowerranked. The findings confirm Atkinson's (1994) view in relation to considering of vital importance employees' awareness of both Kaizen and overall organisational strategy as well as their training to conduct KEs and, in general, adopt a CI attitude. The study's outcome would help the industry managers not only in the perspectives of contingencies but also guide them about understanding the interplay of the strategic resources of the organisation and the capability to gain a competitive advantage by knowing the main obstacles to implement stage of KEs and contribute to the RBV theory perspective (Hitt et al. 2016; Conner and Prahalad 1996). The descriptive analysis shows that these are main barriers as per the respondent's point of views which are not to implement KEs in the organization which future help the industry managers about proper investment to overcome these barriers, for instance, to think about more investment about training about required skills enhancement of the employee, change management practices etc. The outcomes of the study have been supported in the literature, Van Aken et al. (2010) suggested that training-sessions need to be immediately followed by substantial implementation activities in conjunction with a facilitator-coach to provide sufficient assistance for employees to fully comprehend the application of the proper tools and techniques and "learning-by-doing". 
Additionally, the results also support the majority of the studies that indicate that companies commonly backslide to the old ways of working and fail to develop a positive attitude and interpret and apprehend LM and Kaizen as persistent, continuous and never-ending processes (Bhasin 2012) that require a long-term commitment (Garcia-Alcaraz et al. 2017a; 2017b). The findings also complement both practitioners and academics' view, which argue that a positive attitude and commitment of team-members positively affect the implementation and, consequently, the success of KEs. Finally, the consideration of financial limitations as the least essential preventer of KEs is in line with most of the work found in the scholarly literature. Specifically, the initial aim of KEs is to cost-effectively improve existing processes and/or products without investing in new technologies and equipment (Cannas et al. 2018), but utilising low-cost solutions (Murata and Katayama 2010) and exploiting the creativity and knowledge of employees through the implementation of systematic, low-cost problem-solving tools and techniques (Manos 2007). This characteristic differentiates KEs from other improvement methods.

Similarly, the successful implementation of KEs itself depends on multiple contingencies, i.e. CSFs which help managers to understand their importance for the successful deployment of KEs. The results presented in Figure 4 show the prominent importance of 'Systematic and strategic Kaizen event development' in the successful implementation of KEs. As per the contingency theory, it is important to understand the significance of contingency, i.e. CSFs for implementations of improvement initiatives. Thus, the systematic and strategic plan of the organisation is importantly indicated by the results of his study and alignment to the views of Van Aken et al. (2010) and Huls (2005). They suggest that well planned and systematically conducted implementations of improvement initiatives will result in their more effective deployment and results. Similarly, Friedli (1999) considers that systematic and strategic conduction of KEs will deter the so-called 'kamikaze', a strategy previously discussed. This view is, however, contradicted by Glover et al. (2013a), who consider that less planned and structured KEs may leave more freedom to innovative thinking, which will result in better results through the proposal of novel solutions for CI. Based on the ranking scores, all identified CSFs may be considered of more than moderate importance as all of them ranked above the average 2.5 .

As per the analysis shown in Figure 5, 'Lack of a well-defined and thorough event planning process' is the major barrier to the implementation of KEs. To contribute to the RBV theory, the outcome will help managers to recognise the importance of the event planning process. Its shows that a well-defined event planning would help industry managers to prepare an effective agenda 
and plan to get the maximum benefits from the event. The same outcome is validated in the studies of Farris et al. (2006) and Bradley and Willett (2004), which supported the significance of a well-defined and thorough event-planning and its positive impact on goal achievements. In contrast, this finding goes against the research of Glover et al. (2011), which suggests that KEs would be more sustainable and successful if they lack extensive event planning. Next, the two most important identified barriers included 'Lack of monitoring process' and 'Lack of performance measurement'. Friedli (1999) suggests that the successful conduction of KEs is dependant of an effective monitoring process, whereas Pinto et al. (2018) consider that CI activities must not only be adopted and implemented but also monitored and measured on a daily basis. Thus, the results obtained from the present research align with the scholarly literature.

In the same way, in the post-implementation stage, the descriptive statistics-based analysis' outcome contributes to the contingency theory by providing evidence of the significance of CSFs. In particular, the results show that 'Resource support' (e.g. investment funds, technical support, human support, etc.) is considered as one of the most important CSFs for KEs to succeed. The outcomes align with the works of Doolen et al. (2008) and Farris et al. (2006), which highlighted the positive relationship between this factor and the overall perceived success of KEs. However, when it comes to the financial aspect of this factor, organisations should also consider that KEs must focus on cost-effective improvements, hence, there must be a limit on the cost of the solutions. Once again, the findings prove the importance of conducting KEs in a systematic and strategic manner as the lack of this characteristic will result in organisations not obtaining the expected results, see Figure 6. In this respect, this aligns to the views of Van Aken et al. (2010), Schniederjans and Cao (2009), Huls (2005) and Friedli (1999), but it contradicts that of Glover et al. (2013a). Furthermore, the current study also makes a contribution to the RBV theory perspective by providing an understanding of the interplay between the strategic resources of an organisation and its capability to gain a competitive advantage. The results also indicate that 'Insufficient team members problem-solving abilities' also play a significant role in the failure of KEs. This suggests that team members must be appropriately trained in problemsolving techniques and their abilities developed in this respect. Appropriate training of staff and team members are widely recognised in the scholarly literature as an important factor for the success of improvement initiatives (Delgado et al. 2010), hence the results of this study converge with this managerial principle. 'Lack of resource support' and having an effective planning process (i.e. 'excess or lack of event planning process') when conducting KEs were also found to be significant factors as the lack of them may result in their failure. Once more, these two factors are widely accepted, in the scholarly literature, as important elements for the success of not only 
improvement initiatives but also project management in general (Belassi and Tukel 1996). Therefore, it can be concluded that the project characteristic of KEs makes the failure factors studied through CRQ5 as generic factors, comparable to those of other types of projects.

It is widely accepted in the scholarly literature that various managerial aspects, but especially leadership, management commitment and organisational culture are of great significance to achieve sustainability throughout the long journey of lean transformation and CI (e.g. MarinGarcia et al., 2018; Bhamu and Sangwan 2014; Achanga et al., 2006). Thus, the results of this study, see Figure 7, closely align to previous findings presented in the LM and CI literature and emphasise the key role of industry leaders and managers to sustain KEs, and consequently their results.

\section{Practical Contributions}

In this way, the study offers reliable evidence for industrialists regarding the managerial factors that may play a significant role in the effective deployment of KEs. In this line, the outcomes of this study would help industry managers who may aim at driving improvements in the operations of their organisations through the implementation of KEs. First, the study identified the major drivers which play a significant role in the implementation of KEs. As per the analysis of the study, "Reduction of waste and Increase in productivity" are major resulting factors from KEs, followed by "Improvement of quality". This finding would motivate industry managers to invest more in the activities and practises related to KEs implementation so that they can minimise waste and increase productivity.

Along with the main drivers, the findings of the study may guide managers about the major barriers which may hinder the successful implementation of KEs. "Insufficient awareness, Insufficient implementation assistance and Backsliding to the old days of working" are the major barriers followed by "Staff attitude, Insufficient knowledge and Employees' skills". This finding provides an indication to managers regarding what barriers they may face so effective strategic plans are formulated to overcome them.

The results also show that "Systematic and strategic Kaizen Event development" is the main CSF in the successful implementation of KEs. This suggests managers that well planned and systematically conducted implementations of improvement initiatives will result in their more effective deployment and results. The study also indicates that the "Lack of the event planning process" is the major barrier to the implementation of KEs. Therefore, industrialists should carefully plan and design an effective deployment process to effectively implement KEs. 
Finally, this study suggests that "Insufficient team members problem-solving abilities" also have a significant effect on the failure of KEs. Industry managers should focus on how they can provide the appropriate training to their employees, which will enhance their problem-solving abilities. "Lack of resource support" and having an effective planning process when conducting KEs were also found to be significant factors as the lack of them may result in their failure. Managers should focus on these factors to facilitate the implementation of KEs.

\subsection{Unique Contributions of the Research}

This study extends our knowledge, through the following unique contributions, by:

- Providing a clarified convergence of the information and knowledge associated with various characteristics and phases of KEs implementation;

- Contributing to bridging the KEs theory-practice gap created by various divergences found in the scholarly literature and created due to different interpretations by academics and practitioners, see Section 1;

- Helping us to understand the reasons that lead organisations to deploy, or not, KEs;

- Defining the enablers/inhibitors, CSFs and challenges related to the implementation of KEs; and

- Determining the reasons that result in unsuccessful KEs as well as those that motivate organisations to discontinue their use.

These contributions are beneficial for manufacturing industrialists who may aim at driving improvements in the operations of their organisations through the implementation of KEs. Due to the nature of CI and characteristics and wide applicability of KEs (Miller et al. 2014), other industrial sectors such as services, logistics and transport, healthcare etc. can also benefit from the present research.

\section{Concluding Remarks, Limitations and Future Research}

The present paper investigates the implementation and management of KEs in the manufacturing sector from various phases' perspective. In this context, this research is among the very few studies that have thoroughly, systematically and quantitatively explored managerial aspects of this mechanism and its deployment. Thus, the aim of this study was to investigate various managerial aspects that have an effect on the implementation of KEs. With the help of experts' inputs and a literature review, RQs were formulated. Data from 175 manufacturing organisations 
worldwide were collected through a structured questionnaire and analysed through a combined approach by using descriptive statistics and one-way ANOVA tests.

This is a unique type of research that covered all implementation phases (pre-implementation, implementation and post-implementation) of KEs. This research uncovered key drivers that lead organisations to implement KEs, key barriers to implement KEs and divergent CSFs in the successful implementation of KEs. This research also revealed the main barriers that organisations face during the implementation of KEs, key reasons that result in unsuccessful KEs and important motives that stop organisations from running KEs.

Overall, this research has not only brought light regarding some managerial aspects that play a role in the implementation of KEs, but it has also opened up new research streams in the CI field.

The present study grieves from a number of limitations that are essential to be highlighted in order for future studies to address them. Initially, the study was restricted to the manufacturing sector. Thus, further research is needed to consider other industries as KEs' implementation and sustainment of managerial characteristics may be different. Moreover, the study was primarily focused on industrialists, excluding academic and research experts. Hence, further studies may also be underpinned by academic experts and researchers, and not only by pragmatic sources, as a vehicle to expand the KEs body of knowledge.

Similarly, as other studies that followed the same data collection strategy and research approach, the present research also writes from a relatively limited number of regional responses, i.e. 175 in total. Similarly, the Likert-scale rating employed for the study limited the ability of respondents to express opinions other than the pre-set answers. For this reason, it would be beneficial to undertake larger-scale research that focuses on specific regions to consider precise characteristics (e.g. policies, culture, etc.) that may also impact the implementation of KEs. To address the Likert-scale limitation, following a combined quantitative-qualitative research method, e.g. by also conducting interviews in selected companies, would validate the results further. These proposals are part of the future research agenda derived from the present research. Finally, the research is mainly centred on management aspects. For this reason, attributes such as training and operators that may also affect the effective implementation of KEs can be explored as part of future research directions. This can be done through the use of, for example, a combination of quality function deployment and fuzzy logic and within the context of specific industries and countries.

\section{References}


Abolhassani, A., Layfield, K., Gopalakrishnan, B. 2016. "Lean and US manufacturing industry: Popularity of practices and implementation barriers." International Journal of Productivity and Performance Management 65(7): 875-897.

Abrosimov, V., \& Mochalkin, A. 2019, April. Sacrifice as Paradigm of Robot Behavior in Group. In Computer Science On-line Conference (pp. 244-254). Springer, Cham.

Achanga, P., Shehab, E., Roy, R., Nelder, G. 2006. "Critical success factors for lean implementation within SMEs." Journal of Manufacturing Technology Management 17(4): 460-471

Albliwi, S. A., Antony, J., Lim, S.A.H. 2015. "A systematic review of Lean Six Sigma for the manufacturing industry.” Business Process Management Journal 21(3): 665-691.

Álvarez-García, J., Durán-Sánchez, A., del Río-Rama, M.D.L.C. 2018. "Systematic bibliometric analysis on Kaizen in scientific journals.” The TQM Journal 30(4): 356-370.

Andreadis, L., Garza-Reyes, J.A., Kumar, V. 2017. "Towards a conceptual framework for value stream mapping (VSM) implementation: An investigation of managerial factors." International Journal of Production Research 55(23): 7073-7095.

Atkinson, C. 1994. "Continuous improvement: The ingredients of change." International Journal of Contemporary Hospitality Management 6(1/2): 6-8.

Awad, M., Shanshal, Y.A. 2017. "Utilizing Kaizen process and DFSS methodology for new product development.” International Journal of Quality \& Reliability Management 34(3): 378-394.

Ballou, R.H. 2007. Business logistics/supply chain management: planning, organizing, and controlling the supply chain. Pearson Education India, New Delhi.

Barney, J. 1991. Firm resources and sustained competitive advantage. Journal of Management, 17(1): 99-120.

Belassi, W., Tukel, O.I. 1996. "A new framework for determining critical success/failure factors in projects." International Journal of Project Management 14(3): 141-151.

Belekoukias, I., Garza-Reyes, J.A., Kumar, V. 2014. "The impact of lean methods and tools on the operational performance of manufacturing organisations." International Journal of Production Research 52(18): 5346-5366.

Berry, L.L. 1999. Discovering the soul of service: The nine drivers of sustainable business success. Simon and Schuster.

Bhamu, J., Sangwan, K.S. 2014. "Lean manufacturing: Literature review and research issues." International Journal of Operations \& Production Management 34(7): 876-940. 
Bhasin, S. 2012. "Prominent obstacles to lean." International Journal of Productivity and Performance Management 61(4): 403-425.

Binti Aminuddin, N.A., Garza-Reyes, J.A., Kumar, V., Antony. J. 2016. “An analysis of managerial factors affecting the implementation and use of overall equipment effectiveness." International Journal of Production Research 54(15): 4430-4447.

Black, K. U. 2019. Business statistics: for contemporary decision making, Wiley Publishing Co., United Kingdom.

Bortolotti, T., Boscari, S., Danese, P., Medina Suni, H.A., Rich, N., Romano, P. 2018. "The social benefits of kaizen initiatives in healthcare: An empirical study." International Journal of Operations \& Production Management 38(2): 554-578.

Bradley, J.R., Willett, J. 2004. “Cornell students participate in Lord Corporation's kaizen projects.” INFORMS 34(6): 451-459.

Cannas, V.G., Pero, M., Pozzi, R., Rossi, T. 2018. "Complexity reduction and kaizen events to balance manual assembly lines: An application in the field." International Journal of Production Research 56(11): 3914-3931.

Carvalho Ferreira, D.M., Saurin, T.A. 2019. "A complexity theory perspective of kaizen: A study in healthcare." Production Planning \& Control 30(16): 1337-1353.

Cavazos-Arroyo, J., Máynez-Guaderrama, A., \& Valles-Monge, L. 2018. "Kaizen events: an assessment of their impact on the socio-technical system of a Mexican company." Ingeniería y Universidad 22(1): 97-115.

Chan, C.O., Tay, H.L. 2018. "Combining lean tools application in kaizen: A field study on the printing industry." International Journal of Productivity and Performance Management 67(1): 45-65.

Chauhan, A.S., Chandra, G., Singh, Y.P. 2020. "Statistics in Indian forestry: A historical perspective." In Statistical Methods and Applications in Forestry and Environmental Sciences (pp. 1-11). Springer, Singapore.

Chen, J.C., Li, Y., Shady, B.D. 2010. "From value stream mapping toward a lean/sigma continuous improvement process: An industrial case study." International Journal of Production Research 48(4): 1069-1089.

Cherrafi, A., Elfezazi, S., Hurley, B., Garza-Reyes, J.A., Kumar, V., Anosike, A.I., Batista, L. 2019. "Green and Lean: A Gemba-Kaizen model for sustainability enhancement." Production Planning \& Control: The Management of Operations 30 (5-6): 385-399. 
Choudhary, S., Nayak, R., Dora, M., Mishra, N., Ghadge, A. 2019. “An integrated lean and green approach for improving sustainability performance: A case study of a packaging manufacturing SME in the UK." Production Planning \& Control 30(5-6): 353-368.

Cole, R.E. 1992. “The quality revolution.” Production and Operations Management 1(1): 118120.

Conner, K.R., Prahalad, C.K. 1996. “A resource-based theory of the firm: Knowledge versus opportunism." Organization Science 7(5): 477-501.

Cronbach, L.J. 1951. "Coefficient alpha and the internal structure of tests.” Psychometrika 16(3): 297-334.

Delgado, C., Ferreira, M., Castelo Branco, M. 2010. "The implementation of lean six sigma in financial services organizations." Journal of Manufacturing Technology Management 21(4): 512-523.

Doolen, T.L., Van Aken, E.M., Farris, J.A., Worley, J.M., Huwe, J. 2008 "Kaizen events and organizational performance: A field study." International Journal of Productivity and Performance Management 57(8): 637-658.

Dresch, A., Veit, D.R., de Lima, P.N., Lacerda, D.P., Collatto, D.C. 2019. "Inducing Brazilian manufacturing SMEs productivity with Lean tools." International Journal of Productivity and Performance Management 68(1): 69-87.

Erdogan, S., Quesada-Pineda, H., Bond, B. 2017. "An empirical tool to measure the effectiveness of kaizen events: A case study in the wood products industries." Forest Products Journal 67(3): 164-178.

Farris, J., Van Aken, E.M., Doolen, L. 2006. "Studying Kaizen event outcomes and critical success factors: A model-based approach.” IIE Annual Conference Proceedings, 1-7.

Farris, J.A., Van Aken, A.M., Doolen, T.L., Worley, J. 2009. “Critical success factors for human resource outcomes in Kaizen events: An empirical study." International Journal of Production Economics 117(1): 42-65.

Farris, J.A., Van Aken, E.M. 2005. Benchmarking Kaizen event success: Best practices report, Technical Report 05D-02 (41 pages), Virginia Polytechnic Institute and State University, Blacksburg, Virginia.

Farris, J.A., Van Aken, E.M., Doolen, L., Worley, J. 2008. "Learning from less successful Kaizen events: A case study.” Engineering Management Journal 20(3): 10-20.

Field, A. 2017. Discovering statistics using IBM SPSS statistics, Sage Publishing, North American Edition, U.S.A. 
Forrester, P., Shimizu, U., Soriano-Meier, H., Garza-Reyes, J.A., Basso, L. 2010. "Lean production, market share and value creation in the agricultural machinery sector in Brazil.” Journal of Manufacturing Technology Management 21(7): 853-871.

Forza, C. 2002. "Survey research in operations management: A process-based perspective." International Journal of Operations \& Production Management 22(2): 152-194.

Fowler Jr, F.J. 2013. Survey research methods, Sage publications.

Friedli, D. 1999. UK firms may suffer from “kamikaze ${ }^{e e}$ kaizen strategy', The Engineer, $8^{\text {th }}$ November, 14.

Gandhi, S.K., Singh, J., Singh, H. 2019. "Modeling the success factors of Kaizen in the manufacturing industry of northern India: An empirical investigation." IUP Journal of Operations Management 18(4): 54-73.

Garcia-Alcaraz, J.L., Oropesa-Vento, M., Maldonado-Macías, A.A. 2017b. Kaizen Planning, Implementing and Controlling, Springer, Cham, Switzerland.

García-Alcaraz, J.L., Oropesa-Vento, M., Maldonado-Macías, A.A. 2017a. "Descriptive analysis of items: Kaizen planning stage." In Kaizen Planning, Implementing and Controlling (pp. 83-91). Springer, Cham.

García-Alcaraz, J.L., Rivera, D.G., \& Iniesta, A.A. 2013. “Critical success factors for Kaizen implementation in manufacturing industries in Mexico." The International Journal of Advanced Manufacturing Technology 68(1-4): 537-545.

Garza-Reyes, J.A., Kumar, V., Chaikittisilp, S., Hua, T.K. 2018. "The effect of lean methods and tools on the environmental performance of manufacturing organisations." International Journal of Production Economics 200: 170-180.

Gliem, J. A., \& Gliem, R. R. (2003). Calculating, interpreting, and reporting Cronbach's alpha reliability coefficient for Likert-type scales. Midwest Research-to-Practice Conference in Adult, Continuing, and Community Education. (http://hdl.handle.net/1805/344)

Glover, W.J. Farris, J.A., E.M. Van Aken, Doolen, T.L. 2011. "Critical success factors for the sustainability of Kaizen event human resource outcomes: An empirical study." International Journal of Production Economics 132(2): 197-213.

Glover, W.J., Farris, J.A., Van Aken, E.M. 2014. "Kaizen events: Assessing the existing literature and convergence of practices." Engineering Management Journal 26(1): 39-61.

Glover, W.J., Farris, J.A., Van Aken, E.M. 2015. "The relationship between continuous improvement and rapid improvement sustainability." International Journal of Production Economics 53(13): 4068-4086. 
Glover, W.J., Farris, J.A., Van Aken, E.M., Doolen, T.L. 2011. "Critical success factors for the sustainability of Kaizen event human resource outcomes: An empirical study." International Journal of Production Economics 132(2): 197-213.

Glover, W.J., Farris, J.A., Van Aken, E.M., Doolen, T.L. 2013b. "Kaizen event result sustainability for lean enterprise transformation." Journal of Enterprise Transformation 3: $136-160$.

Glover, W.J., Liu, W.H., Farris, J.A., Van Aken, E.M. 2013. "Characteristics of established kaizen event programs: an empirical study." International Journal of Operations \& Production Management 33(9): 1166-1201.

Glover, W.J., Liu, W.H., Farris, J.A., Van Aken, E.M. 2013a. "Characteristics of established kaizen event programs: An empirical study." International Journal of Operations \& Production Management 33(9): 1166-1201.

Golinska, P., Romano, C.A. (Eds.). 2012. Environmental issues in supply chain management: new trends and applications, Springer Science \& Business Media.

Gonzalez-Aleu, F., Van Aken, E.M., Cross, J., Glover, W.J. 2018. “Continuous improvement project within Kaizen: critical success factors in hospitals." The TQM Journal 30(4): $335-355$.

Habidin, N.F., Hashim, S., Fuzi, N.M., Salleh, M.I. 2018. “Total productive maintenance, kaizen event, and performance." International Journal of Quality \& Reliability Management 35(9): 1853-1867.

Hair, J.F., Black, W.C., Babin, B.J., Anderson, R.E. 2013. Multivariate data analysis: Pearson new international edition, Pearson Higher Ed.

Harkness, J., Pennell, B.E., Schoua-Glusberg, A. 2004. "Survey questionnaire translation and assessment." Methods for Testing and Evaluating Survey Questionnaires 546: 453-473.

Hitt, M.A., Xu, K., Carnes, C.M. 2016. "Resource based theory in operations management research.” Journal of Operations Management 41: 77-94.

Horwitz, F.M., Bravington, D., Silvis, U. 2006. “The promise of virtual teams: Identifying key factors in effectiveness and failure.” Journal of European Industrial Training 30(6): 472494.

Howell, V. 2012. "Total productive maintenance: A strategy for your lean journey." Ceramic Industry 162(10): 18-23.

Huls, K. 2005. "The Antioch company brings lean into the office." Journal of Organizational Excellence 24(4): 31-38. 
Janjić, V., Todorović, M., Jovanović, D. 2019. "Key success factors and benefits of Kaizen implementation.” Engineering Management Journal 1-9, https://doi.org/10.1080/104292 $\underline{47.2019 .1664274}$

Kamble, S., Gunasekaran, A., Dhone, N.C. 2020. "Industry 4.0 and lean manufacturing practices for sustainable organisational performance in Indian manufacturing companies." International Journal of Production Research 58(5): 1319-1337.

Khan, S.A., Kaviani, M.A., Galli, B.J., Ishtiaq, P. 2019. "Application of continuous improvement techniques to improve organization performance.” International Journal of Lean Six Sigma 10(2): 542-565.

Kirby, K., Greene, B. 2003. "How value stream type affects the adoption of lean production tools and techniques." in Proceedings of the 2003 Industrial Engineering and Research Conference, 18-20.

Kumar, S., Dhingra, A., Singh, B. 2018. Lean-Kaizen implementation. Journal of Engineering, Design and Technology 16 (1): 143-160.

Kumar, S., Dhingra, A.K., Singh, B. 2018a. "Kaizen selection for continuous improvement through VSM-FUZZY-TOPSIS in small-scale enterprises: An Indian case study." Advances in Fuzzy Systems 1-10.

Kumar, S., Dhingra, A.K., Singh, B. 2018b. "Process improvement through Lean-Kaizen using value stream map: A case study in India." The International Journal of Advanced Manufacturing Technology 96(5-8): 2687-2698.

Kumar, S., Harms, R. 2004. "Improving business processes for increased operational efficiency: A case study." Journal of Manufacturing Technology Management 15(7): 662-674.

Kurpjuweit, S., Reinerth, D., Schmidt, C.G., Wagner, S.M. 2019. "Implementing visual management for continuous improvement: barriers, success factors and best practices." International Journal of Production Research 57(17): 5574-5588.

Larson, P.D., Foropon, C. 2018. "Process improvement in humanitarian operations: an organisational theory perspective.” International Journal of Production Research 56(21): 6828-6841.

Lee, Q. 2007. “Implementing lean manufacturing.” Management Services 51(3): 14-23.

Lima, M.J.D.R.F., Todaro, M.C., dos Santos Rocha, M. 2018. "A methodological approach for kaizen events in assembly lines." Journal of Lean Systems 3(1): 46-65.

Line, L.A. 2007. "Kaizen assembly: Designing, constructing, and managing a lean assembly line June 28, 2006." Assembly Automation 27(1). 
Liu, W.H., Asio, S., Cross, J., Glover, W.J., Van Aken, E. 2015. "Understanding team mental models affecting Kaizen event success.” Team Performance Management 21(7/8): 361385

Luthra, S., Garg, D., Haleem, A. 2015. “An analysis of interactions among critical success factors to implement green supply chain management towards sustainability: An Indian perspective.” Resources Policy 46: 37-50.

Manos, A. 2007. "The Benefits of Kaizen and Kaizen Events." Quality Progress 40(2): 47-48.

Marin-Garcia, J.A., Juarez-Tarraga, A., Santandreu-Mascarell, C. 2018. "Kaizen philosophy: The keys of the permanent suggestion systems analyzed from the workers' perspective." TQM Journal 30(4): 296-320.

Medinilla, Á. 2014. "Why and How Kaizen Fails”, In Agile Kaizen (pp. 21-36). Springer, Berlin, Heidelberg.

Mika, G.L. 2006. Kaizen Event Implementation Manual, 5th ed., Society of Manufacturing Engineers (SME), Dearborn, Michigan.

Miller, J., Wroblewski, M., Villafuerte, J. 2014. "Creating a Kaizen culture: Align the organization, achieve breakthrough results, and sustain the gains." Journal for Quality \& Participation 37(2): 13-13, 1/3p.

Mitra Debnath, R. 2019. "Enhancing customer satisfaction using Kaizen: A case study of Imperial Tobacco Company (ITC)." Journal of Advances in Management Research 16(3): 277-293.

Mohammad, I.S., Oduoza, C.F. 2019. "Lean-excellence business management for manufacturing SMEs focusing on KRI." International Journal of Productivity and Performance Management 69(3): 519-539.

Murata, K., Katayama, H. 2010. "Development of Kaizen case-base for effective technology transfer-a case of visual management technology." International Journal of Production Research 48(24): 7265-7287.

Nakamori, T., Takahashi, K., Han, B.T., McIver, D. 2019. "Understanding KAIZEN practice in Japanese overseas manufacturing: A framework." International Journal of Knowledge Management Studies 10(3): 271-298.

Natale, J., Uppal, R., Maggelet, N., Wang, S., Taylor, J., Ogrinc, M. 2013. “The impacts of Kaizen event duration on Kaizen success and logistics." In Proceedings of the 2013 Industrial and Systems Engineering Research Conference, 971-978. 
Ng, E.H., Beruvides, M.G., Simonton, J.L, Chiu-Wei, C.C., Peimbert-Garcia, R.E. 2012. Public transportation vehicle maintenance and regional maintenance center: An analysis of existing literature.” Engineering Management Journal 24(3): 43-51.

Nishat Faisal, M. 2010. "Sustainable supply chains: A study of interaction among the enablers." Business Process Management Journal 16(3): 508-529.

Nunnally, J.C., Bernstein, I.H. 1994. Psychometric Theory, McGraw-Hill, New York.

Oropesa Vento, M., Garcia Alcaraz, J.L., Maldonado Macias, A.A., Martinez Loya, V. 2016. "The impact of managerial commitment and Kaizen benefits on companies." Journal of Manufacturing Technology Management 27(5): 692-712.

Ortiz, C. 2006. "All-out kaizen: A continuous improvement plan delivers change to the production floor... and dollars to the bottom line." Industrial Engineer 38(4): 30-35.

Palmer, V.S. 2001. "Inventory management KAIZEN." in Engineering Management for Applied Technology, 2001. EMAT 2001. Proceedings. 2nd International Workshop on. IEEE, pp. $55-56$.

Pinto, J.L., Matias, J.C.O., Pimentel, C., Azevedo, S.G. 2018. Just in Time factory: Implementation through lean manufacturing tools, in: Management for Professionals, Springer, Berlin.

Piyathanavong, V., Garza-Reyes, J.A., Kumar, V., Maldonado-Guzmán, G., Mangla, S.K. 2019. "The adoption of operational environmental sustainability approaches in the Thai manufacturing sector." Journal of Cleaner Production 220: 507-528.

Rivera-Mojica, D., Rivera-Mojica, L. 2004. 'Critical success factors for kaizen implementation', In Lean Manufacturing in the Developing World (pp. 157-178). Springer, Cham.

Robson, C. 2011. Real World Research, 3rd ed. John Wiley, Chichester.

Roopa, S., Rani, M.S. 2012. "Questionnaire designing for a survey.” Continuing Education, 46 (December): 273-277.

Schniederjans, M., Cao, Q. 2009. "Alignment of operations strategy, information strategic orientation,and performance: an empirical study." International Journal of Production Research 47(10): 2535-2563.

Scott, W.R. 1981. Organizations: Rational, natural, and open systems. Englewood Cliffs NJ: Prentice Hall Inc.

Sekaran, U., Bougie, R. 2016. Research methods for business: A skill building approach. John Wiley \& Sons.

Sheridan, J.H. 2000. “Lean Sigma's synergy.” Industry Week/IW, Penton Publishing 249(17): $81-82$. 
Sheridan, J.H., Jusko, J. 2000. “A new attitude.” Industry Week/IW, 249(10): 16-24.

Singh, J., Singh, H. 2009. "Kaizen philosophy: A review of literature." IUP Journal of Operations Management 8(2): 51-72.

Singh, J., Singh, H. 2012. "Continuous improvement approach: State-of-art review and future implications." International Journal of Lean Six Sigma 3(2): 88-111.

Sitkin, S.B. 1992. "Learning through failure: The strategy of small losses." Research in Organizational Behaviour 14: 231-266.

Sitkin, S.B., Sutcliffe, K.M., Schroeder, R.G. 1994. "Distinguishing control from learning in total quality management: a contingency perspective." Academy of Management Review 19(3): 537-564.

Smalley, A., Kato, I. 2010. Toyota Kaizen Methods: Six Steps to Improvement, CRC Press, Boca Raton, FL.

Sousa, R., Voss, C.A. 2008. "Contingency research in operations management practices." Journal of Operations Management 26(6): 697-713.

Sprovieri, J. 2008. "Quality in Assembly-Want fast improvement? Try a kaizen blitz." Assembly, 51(11): 8-15.

Stelson, P., Hille, J., Eseonu, C., Doolen, T. 2017. "What drives continuous improvement project success in healthcare?." International Journal of Health Care Quality Assurance 30(1): $43-57$.

Stentoft, J., Freytag, P.V. 2019. "Improvement culture in the public mental healthcare sector: Evaluation of implementation efforts." Production Planning \& Control: 1-17.

Stewart, J. 2011. The Toyota Kaizen Continuum: A Practical Guide to Implementing Lean, CRC Press, Boca Raton, FL.

Suárez-Barraza, M.F., Ramis-Pujol, J. 2010. "Implementation of Lean-Kaizen in the human resource service process: A case study in a Mexican public service organisation." Journal of Manufacturing Technology Management 21(3): 388-410.

Sunder M.V., Prashar, A. 2020. "Empirical examination of critical failure factors of continuous improvement deployments: Stage-wise results and a contingency theory perspective." International Journal of Production Research, 1-22.

Tavana, M., Shaabani, A., Valaei, N. 2020. "An integrated fuzzy framework for analyzing barriers to the implementation of continuous improvement in manufacturing." International Journal of Quality \& Reliability Management, https://doi.org/10.1108/ IJQRM-06-2019-0196 
Taylor, D., Taylor, D.H., Brunt, D. 2001. Manufacturing operations and supply chain management: the lean approach, Cengage Learning EMEA, Mitcham, Surrey.

Tortorella, G.L., Vergara, A.M.C., Garza-Reyes, J.A., Sawhney, R. 2020. “Organizational learning paths based upon industry 4.0 adoption: An empirical study with Brazilian manufacturers.” International Journal of Production Economics 219: 284-294.

Ueki, Y., Guaita Martínez, J.M. 2019. “The impact of engineers' skills and problem-solving abilities on process innovation." Economic research-Ekonomska istraživanja: 1-20.

Uppal, R., Natale, J., Liszka, A., Wang, S., Taylor, J. 2012. "Process improvement at a newly established emergency department: A Kaizen approach." IIE Annual Conference Proceedings, Institute of Industrial and Systems Engineers (IISE).

Van Aken, E.M., Farris, J.A., Glover, W.J., Letens, G. 2010. “A framework for designing, managing, and improving Kaizen event programs." International Journal of Productivity and Performance Management 59(7): 641-667.

Villar-Fidalgo, L., Espinosa Escudero, M.M., Dominguez Somonte, M. 2019. "Applying kaizen to the schedule in a concurrent environment." Production Planning \& Control 30(8): 624-638.

Vo, B., Kongar, E., \& Barraza, M. F. S. 2019. "Kaizen event approach: a case study in the packaging industry." International Journal of Productivity and Performance Management 68 (7), 1343-1372.

Zailani, S., Govindan, K., Shaharudin, M.R., Kuan, E.E.L. 2017. "Barriers to product return management in automotive manufacturing firms in Malaysia." Journal of Cleaner Production 141: 22-40.

Zanin, M., Wang, S., Hillman, M. 2011. "Implementing a Kaizen in an aged and over-utilized hospital emergency department." IIE Annual Conference Proceedings. Institute of Industrial and Systems Engineers (IISE). 


\section{Appendix A}

Table A1. Questionnaire's outline

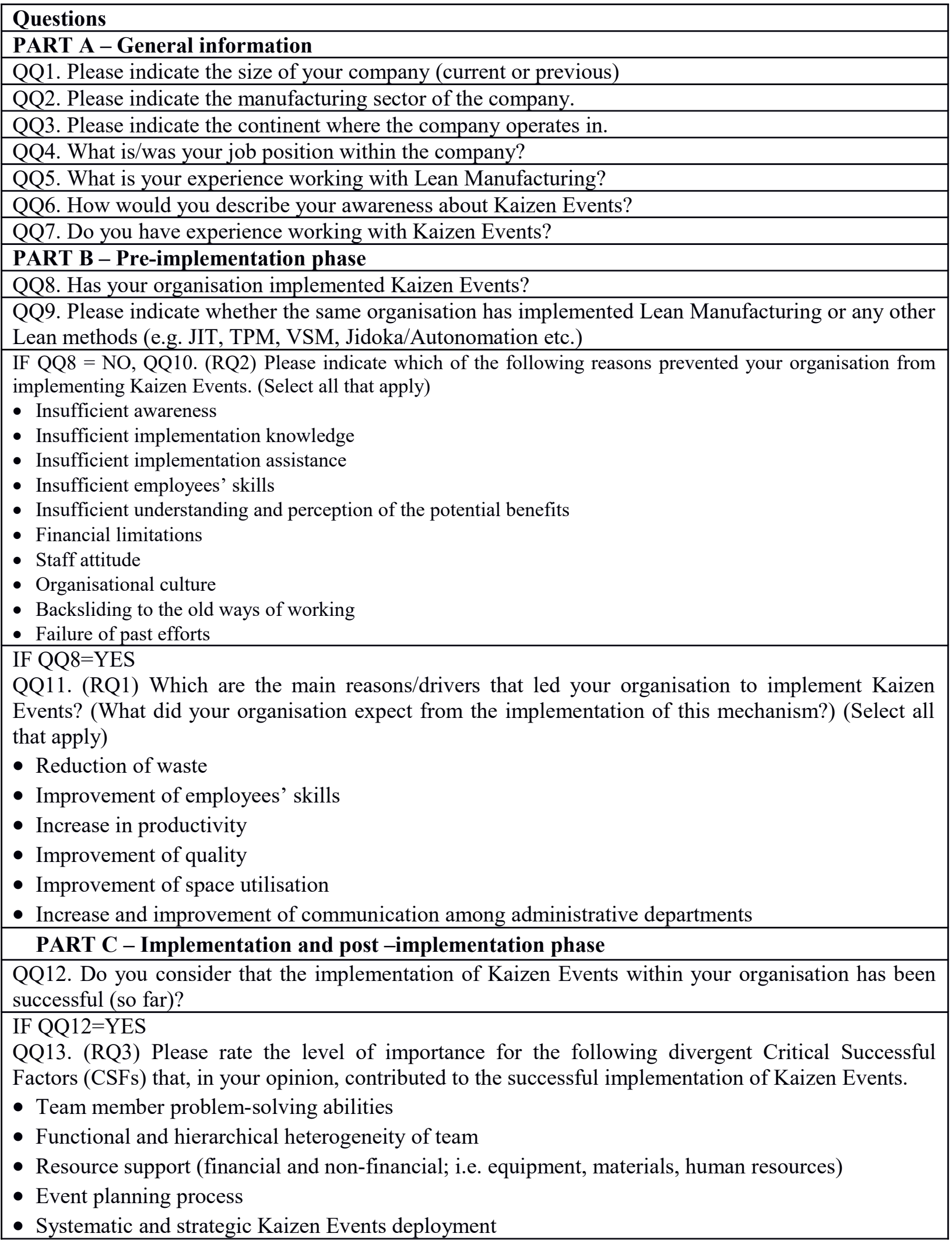


IF QQ12=NO, QQ14. (RQ4) Which are the main barriers that led your organisation to stop implement Kaizen Events? (Select all that apply)

- Lack of management and resource support

- Lack of well-defined and thorough event planning

- Lack of extensive event planning

- Kamikaze strategy

- Lack of performance measurement

- Lack of monitoring process

- Lack of rewards and recognition for team members

- Lack of organisational policies and procedures

QQ15 (RQ4) Please rate the following statements regarding the team design barriers/challenges that your organisation faced during the implementation of Kaizen Events?

- The existence of more experienced team leaders and team members reduced teammembers' participation and decision-making, having a negative impact on goal achievement and team members' knowledge, skills and abilities

- Lack of experienced team leaders and team members with increased problem-solving skills negatively impacted goal achievement

- Including most team-members from work-areas resulted in biased decision-making

- Functional heterogeneity negatively impacted team members' attitude toward Kaizen Events

- Lack of functional heterogeneity negatively impacted the bonds between competing departments

- Including workers from competing departments or organisations had a negative impact on team bonds and performance

- Including managers on the team did not encourage front-line empowerment

QQ16 (RQ4) Please rate the following statements regarding the organisational barriers/challenges that your organisation faced during the implementation of Kaizen Events.

- The lack of management and resource support (financial and non-financial; i.e. equipment, materials, human resources) negatively impacted attitudes towards Kaizen Events and overall perceived success

- Lack of well-defined and thorough event planning activities negatively impacted the implementation and success of Kaizen Events

- Very extensive planning before the event negatively impacts the success and sustainability of Kaizen Events

QQ17 (RQ4) Please rate the following statements regarding the barriers/challenges that your organisation faced during the implementation of Kaizen Events with respect to Kaizen Events deployment.

- Implementation of "Kamikaze" Kaizen strategy (haphazard, unsystematic Kaizen Events) resulted to unsuccessful Kaizen Events

- Lack of appropriate performance measurements negatively impacted Kaizen Events success

- Lack of appropriate progress monitoring negatively impacted Kaizen Events success

- Lack of rewards and recognition for team members negatively impacted Kaizen Events success

- Lack of organisational policies and procedures to support Kaizen Events implementation

IF QQ15=NO, QQ18 (RQ5) Please rate the impact that each one of the following factors had on the unsuccessful implementation of Kaizen Events.

- Insufficient team members' problem-solving abilities

- Lack of functional and hierarchical heterogeneity

- Lack of resource support (financial and non-financial; i.e. equipment, materials, human resources)

- Excess or lack of event planning process

- Lack of systematic and strategic Kaizen Events deployment 
QQ19 Did your organisation continues implementing Kaizen Events?

IF QQ19=NO, QQ20. (RQ6) Please indicate the reasons that stopped your organisation from running Kaizen Events. (Select all that apply)

- Lack of leadership and management support

- Lack of financial capabilities support

- Inappropriate organisational culture

- Negative employees' attitude towards KEs

- Lack of organisational policies and procedures

- Lack of systematic and strategic KEs

- Lack of appropriate progress monitoring

- Lack of appropriate performance measurements

- Lack of rewards and recognition for team members

${ }^{*} Q Q=$ Questionnaire Question 